\title{
5. LATE QUATERNARY CALCAREOUS NANNOFOSSILS FROM THE SEDIMENTED MIDDLE VALLEY OF THE JUAN DE FUCA RIDGE, LEG 1391
}

\author{
Shaozhi Mao ${ }^{2,3}$ and Sherwood W. Wise, Jr. ${ }^{2}$
}

\begin{abstract}
Upper Quaternary calcareous nannofossils contained in drill cores taken in the heavily sedimented Middle Valley of the northern Juan de Fuca Ridge in the northeast Pacific Ocean (Ocean Drilling Program Leg 139) are investigated. The host sediments have been subjected at depth to high temperatures and hot hydrothermal fluids that have altered or destroyed in part or in toto the nannofossil assemblages, thereby raising at several sites the level of the first (deepest) stratigraphic occurrence of nannofossils or of the important Emiliania huxleyi datum. The degree of alteration of the nannofossil assemblages is dependent on the intensity of the hydrothermal activity, which is indicated by paleotemperatures derived independently from studies of color alteration of palynomorphs and by vitrinite reflectance (Mao et al., this volume). State of preservation and the downhole level at which assemblages have been destroyed correlate well with the inferred paleotemperature estimates. Destruction of the assemblages appears to be species selective and follows in general the dissolution rankings determined independently by others for Recent nannofossils of the Pacific basin. More systematic correlation of these phenomena is hampered, however, by the fact that nannofossil preservation is already quite variable at the time of deposition because of the predominance of turbidite activity in the study area.
\end{abstract}

\section{INTRODUCTION}

During Leg 139 of the Ocean Drilling Program (ODP), JOIDES Resolution drilled Middle Valley of the northern Juan de Fuca Ridge (northeast Pacific Ocean). This was the first part of a proposed two-leg program to investigate hydrothermal processes and products along a sedimented ocean ridge. Although magma is supplied in abundance along most of the Juan de Fuca Ridge, in the drilling area (a deep extensional rift filled with thick Pleistocene sediments), the magma supply is significantly diminished. However, hot hydrothermal fluids from the underlying igneous basement have interacted with the sediments. Twenty-two holes at four sites (Fig. 1; Table 1) were drilled in the valley, where the sediments are mainly hemipelagic clays and turbidite sequences. The purpose of this paper is to describe the calcareous nannofossils from this unusual geological setting and to assess the effects of the hydrothermal fluids on the fossil assemblages.

We are aware of no previous studies of nannofossil assemblages that have been subjected to hydrothermal activity. However, the intrusion of high-temperature hydrothermal solutions containing dissolved chemical compounds and gas (such as $\mathrm{CO}_{2}$ ) should result in the destruction of nannofossil ultrastructures and/or the partial or total dissolution of the nannofossil assemblages. Similarly, high heat flow would raise in-situ pore fluid temperatures, thereby increasing reaction rates and promoting the dissolution of nannofossils. Consequently, where strong hydrothermal activity has occurred, one might expect poor preservation, with any assemblages recorded representing only the distorted remnants of the original material. In addition, the first (deepest) stratigraphic occurrences of some key taxa may be found higher in the section than expected, a circumstance that would hamper the development of a precise biostratigraphy.

The specific goals of this paper are to establish the calcareous nannofossil stratigraphy as precisely as possible, to estimate sedimentation rates where feasible, and to survey the diagenetic effects of hydrothermal activity on nannofossil assemblages. In particular, we

\footnotetext{
1 Mottl, M.J., Davis, E.E., Fisher, A.T., and Slack, J.F. (Eds.), 1994. Proc, ODP, Sci. Results, 139: College Station, TX (Ocean Drilling Program).

${ }^{2}$ Department of Geology, Florida State University, Tallahassee, Florida 32306, U.S.A

${ }^{3}$ Present address: Department of Geology, China University of Geosciences, Xueya Road 29, 100083, Beijing, People's Republic of China
}

will explore the relationship between nannofossil preservation and hydrothermal temperature.

Four hundred and ninety-seven samples from 12 holes at four sites were examined. One hundred ninety-one samples are barren of nannofossils, accounting for $38.5 \%$ of the total (Table 2). Among the 306 fossiliferous samples, 44 contain rare and poorly preserved specimens of a single species, Coccolithus pelagicus.

\section{MATERIALS AND METHODS}

Smear slides were prepared directly from the raw sediment samples and were investigated by conventional light microscopy. For scanning electron microscope (SEM) studies, the raw sediments were disaggregated and settled to remove coarse particles and to concentrate the fossils.

The distribution, preservation, and abundance of nannofossils for each hole are presented in range charts (Tables 3-10). Because calcareous nannofossils in the study area constitute only a small portion of the sediment, the relative abundance of individual species and assemblages were estimated as follows (at a magnification of $1560 \times$ ):

$$
\begin{aligned}
& A=\text { abundant },>10-100 \text { specimens/field of view; } \\
& C=\text { common, } 1-10 \text { specimens/field; } \\
& F=\text { few, } 1 \text { specimen } / 2-10 \text { fields; } \\
& R=\text { rare } 1 \text { specimen } / 11-100 \text { fields; } \\
& B=\text { essentially barren, } 1 \text { specimen }>100 \text { fields. }
\end{aligned}
$$

Qualitative descriptions of nannofossil preservation in each sample were recorded as follows:

$\mathrm{M}=$ moderate, significant evidence of secondary alteration via etching and/or destruction of some elements; identification of species generally not impaired.

$\mathrm{P}=$ poor, specimens with severe etching and destruction of some elements; identification of some species significantly impaired.

$\mathrm{VP}=$ very poor, specimens strongly altered, showing rough outlines with structures heavily damaged due to hydrothermal alteration.

For each sample at least 100 fields were scanned. The biostratigraphic zonation employed here is that of Martini (1971). Additional zonal markers suggested by Gartner (1977), Gard (1988), Verbeek (1990), Rio et al. (1990), and Sato et al. (1991) were also used wherever 


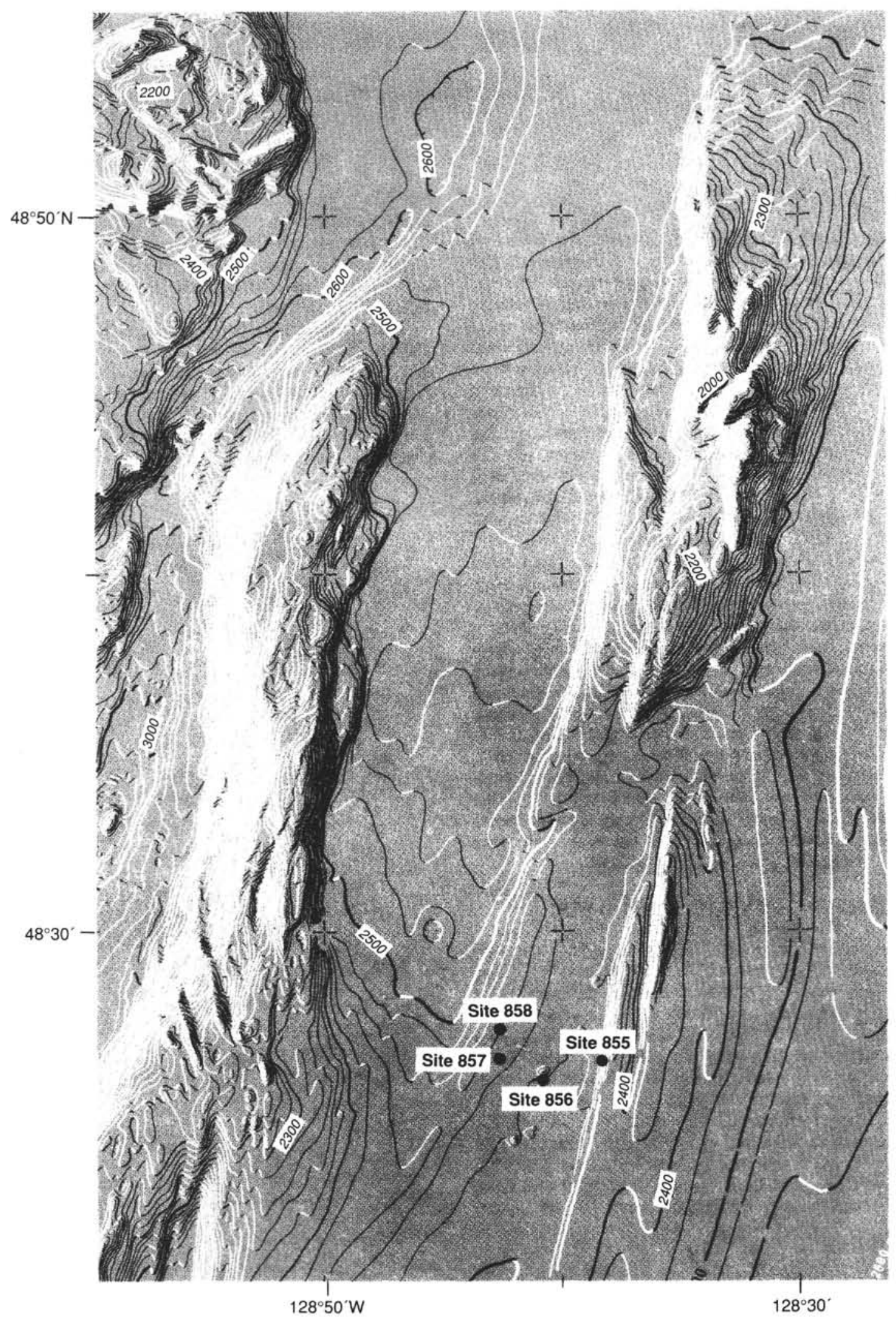

Figure 1. Location map of study area. 
Table 1. Water depth and location of Leg 139 sites.

\begin{tabular}{ccc}
\hline Site & $\begin{array}{c}\text { Latitude and } \\
\text { longitude }\end{array}$ & $\begin{array}{c}\text { Water } \\
\text { depth }(\mathrm{m})\end{array}$ \\
\hline 855 & $48^{\circ} 26.56^{\prime} \mathrm{N}$ & \\
& $128^{\circ} 38.27^{\prime} \mathrm{W}$ & 2456 \\
856 & $48^{\circ} 26.20^{\prime} \mathrm{N}$ & \\
& $128^{\circ} 40.84^{\prime} \mathrm{W}$ & 2406 \\
857 & $48^{\circ} 26.5^{\prime} \mathrm{N}$ & \\
& $128^{\circ} 42.6^{\prime} \mathrm{W}$ & 2433 \\
858 & $48^{\circ} 27.34^{\prime} \mathrm{N}$ & \\
& $128^{\circ} 42.54^{\prime} \mathrm{W}$ & 2420 \\
\hline
\end{tabular}

possible, particularly the Emiliania huxleyi acme of Gartner (1977). Most of the zonal markers have previously been correlated with the geomagnetic-reversal time scale of Berggren et al. (1985).

\section{BIOSTRATIGRAPHIC AND TAXONOMIC CONCEPTS}

During the past fifteen years Quaternary nannofossil biostratigraphy has been intensively studied in an attempt to improve precision for climate-change studies. Gartner (1977) proposed seven biozones for this time interval. Others have tried quantitative or semiquantitative methods to divide some genera into different morpho-groups (rather than species) that could be related to biostratigraphic zones (Matsuoka and Okada, 1989; Gard, 1988; Gard and Backman, 1990). For example, Gard (1988) subdivided four late Quaternary zones of Gartner (1977) into 11 zones based on the study of Gephyrocapsa.

In the study area, because of the hydrothermal activity and the dominantly turbiditic sedimentation, the nannofossil assemblages extracted from the sediments may represent the final products of gravity sorting, mechanical erosion, and hydrothermal alteration. This makes it difficult to establish a detailed stratigraphic subdivision such as those of Gard (1988) and Matsuoka and Okada (1989). However, we found that the standard zonation schemes and many of the new biostratigraphic datums proposed by the authors mentioned above are still useful for this study.

In general, nannofossil assemblages in the study area are of low diversity, ranging from only one to about 20 taxa, with Gephyrocapsa spp., Emiliania huxleyi, and Coccolithus pelagicus the most dominant. Gephyrocapsa species are difficult to distinguish with both the light microscope (LM) and the SEM (Perch-Nielsen, 1985). The taxonomy of the genus is ambiguous and controversial, with many forms difficult to differentiate at the species level. Matsuoka and Okada (1990) roughly divided Gephyrocapsa into two categories, small (specimens $\sim 2.0-3.5 \mu \mathrm{m}$ ) and large (specimens $>3.5 \mu \mathrm{m}$ ). The small category may consist of several species such as $G$. aperta, $G$. ericsonia, $G$. pelta, and $G$. sinuosa. For the large forms, these authors noticed time-progressive changes in overall size and bridge angle and identified with the aid of statistics four groups (A, B, C, and D). Each of these four groups has a different stratigraphic range.

Gard (1988) also observed during her study of European Arctic seas that Gephyrocapsa spp. showed characteristic morphological changes through time. Three basic morphotypes of Gephyrocapsa were easily recognized under the light microscope as follows: (1) slightly ovoid specimens about $2.5-5 \mu \mathrm{m}$ in length with a bridge spanning an open central area (described variously as G. muellerae Bréhérét or G. oceanica Kamptner, and referred to as $G$. muellerae by Gard); (2) distinctly small specimens, $<2.5 \mu \mathrm{m}$, usually only about $1 \mu \mathrm{m}$ in length (described variously as $G$. aperta Kamptner, $G$. ericsonii McIntyre and Bé, and/or G. theyerii Pujos, and referred to as $G$. aperta by Gard); (3) Specimens $2.5-5 \mu \mathrm{m}$ in diameter with
Table 2. Numbers of samples examined and percentage of fossiliferous samples in each hole.

\begin{tabular}{crrc}
\hline Holes & $\begin{array}{c}\text { Total } \\
\text { samples }\end{array}$ & $\begin{array}{c}\text { Fossiliferous } \\
\text { samples }\end{array}$ & $\begin{array}{c}\text { \% of } \\
\text { total }\end{array}$ \\
\hline 855A & 24 & 24 & 100 \\
855B & 8 & 7 & 87.5 \\
855C & 44 & 39 & 88.5 \\
855D & 1 & 0 & 0 \\
856A & 67 & 31 & 46 \\
856B & 53 & 1 & 2 \\
857A & 95 & 89 & 93.5 \\
857C & 99 & 51 & 51.5 \\
$858 \mathrm{~A}$ & 60 & 40 & 65.5 \\
858B & 10 & 5 & 50 \\
858C & 13 & 8 & 61.5 \\
858D & 23 & 11 & 48 \\
Total & 497 & 306 & 61.5 \\
\hline
\end{tabular}

closed or nearly closed central area spanned by a short and not clearly visible bridge under the light microscope (referred to as $G$. carribeanica Boudreaux and Hay by Gard).

In their study of calcareous nannofossils from the western Mediterranean, Rio et al. (1990) stated that the overall size of gephyrocapsids does indeed represent a plain morphometric parameter and can be used to consistently correlate lower Pleistocene sequences from geographically distant areas. They split the group into four categories as follows: (1) specimens $<3.5 \mu \mathrm{m}$ in size, labeled "small Gephyrocapsa spp."; (2) specimens $>4 \mu \mathrm{m}$ and $<5.5 \mu \mathrm{m}$ in size with a central opening, labeled G. oceanica s.l.; (3) specimens $>5.5 \mu \mathrm{m}$, labeled "large Gephyrocapsa spp."; (4) specimens usually 4-6 $\mu \mathrm{m}$ in size with an open central area and a bridge nearly aligned with the short axis of the placolith (labeled Gephyrocapsa sp. 3 by Rio, 1982), comparable to G. parallela of Takayama and Sato (1987) or G. omega Bukry of most other authors.

Gard's classification of Gephyrocapsa is employed as the basic scheme for this study in view of the state of preservation and the geographic proximity of the study area to the subarctic area. The other schemes are also referenced. We divide Gyphyrocapsa into four groups by splitting Group 1 of Gard into two groups. Our Group 1 is equal to the smaller size $(\sim 2.5-3.5 \mu \mathrm{m})$ fraction of Gard's Group 1 while our Group 4 is equal to the larger size $(>3.5-5 \mu \mathrm{m})$. Our Groups 2 and 3 are the same as those of Gard. Therefore, our Group 4 corresponds to Gephyrocapsa sp. D of Matsuoka and Okada (1989) or Gephyrocapsa oceanica of most authors.

\section{RESULTS}

\section{Site 855}

Four holes were drilled at Site 855 (water depth $=2456 \mathrm{~m}$ ) along a normal fault that forms the eastern topographic boundary of the sedimented rift valley; all recovered upper Pleistocene sediments. Three holes produced the most fossiliferous samples of all the drill sites; however, the species diversity is as low as at the other three sites, consisting of only 1 to 16 taxa (Tables 3-5).

The marker species, Emiliania huxleyi, is common in samples above $14.58 \mathrm{mbsf}$ at Hole $855 \mathrm{~A}$ and above $17.04 \mathrm{mbsf}$ at Hole $855 \mathrm{C}$, but is few to rare in samples below these depths; it never is abundant in any holes of this site. According to Perch-Nielsen (1985) this species presently exhibits its widest distribution. It is found in high latitudes as well as in the tropics. It also is one of the last species to be dissolved when sinking to great ocean depths (Schneidermann, 1977). However, it is so delicate in structure, with many isolated " $T$ "-shaped elements along the distal shield, that heat flow and hydrothermal fluids may destroy it partially or completely. As a result, the numbers of $E$. huxleyi in nannofossil assemblages may be reduced or altered. At Site 855 the first occurrence of $E$. huxleyi is difficult to detect because of its low 
Table 3. Distribution of calcareous nannofossils, Hole 855A, Leg 139.

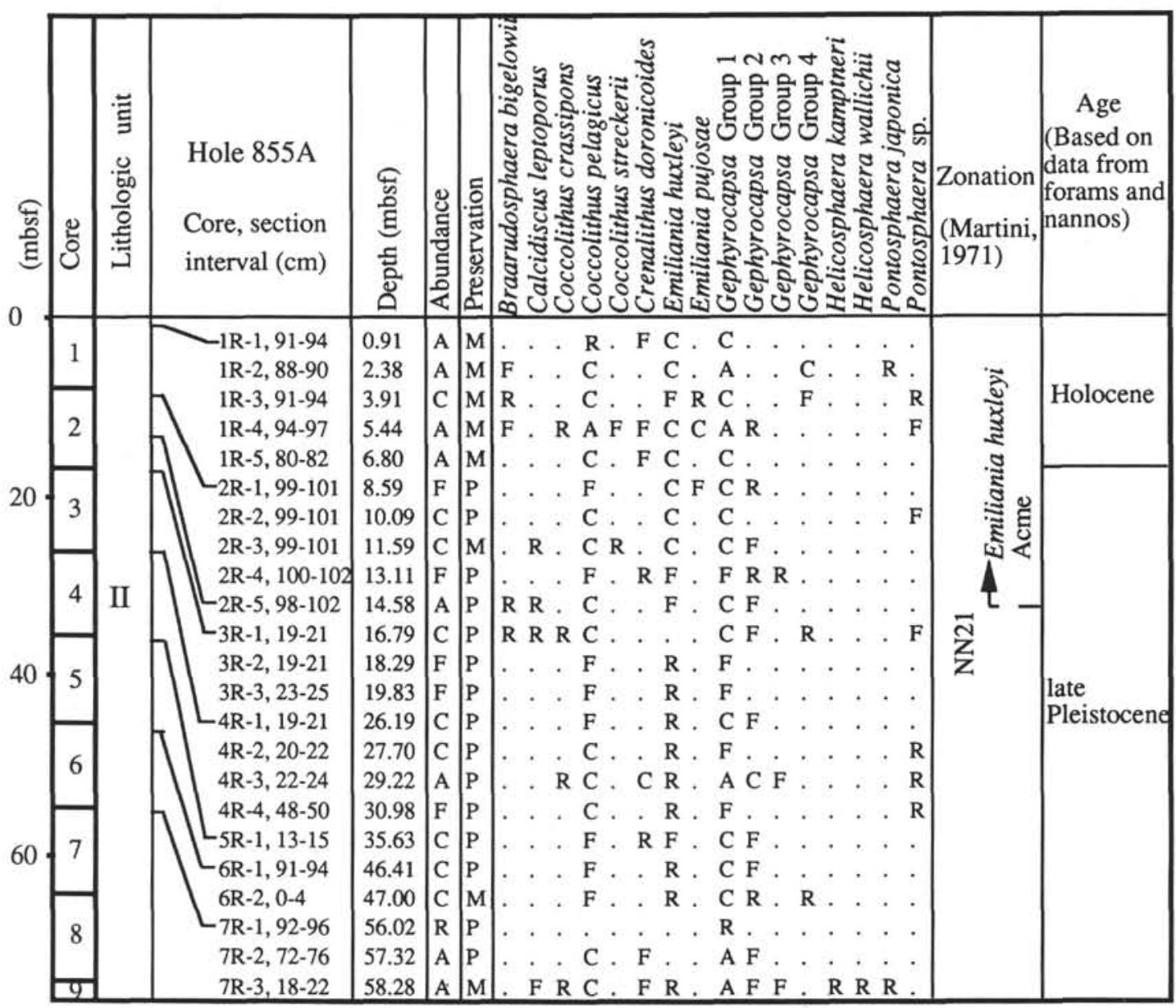

Table 4. Distribution of calcareous nannofossils, Hole 855B, Leg 139.

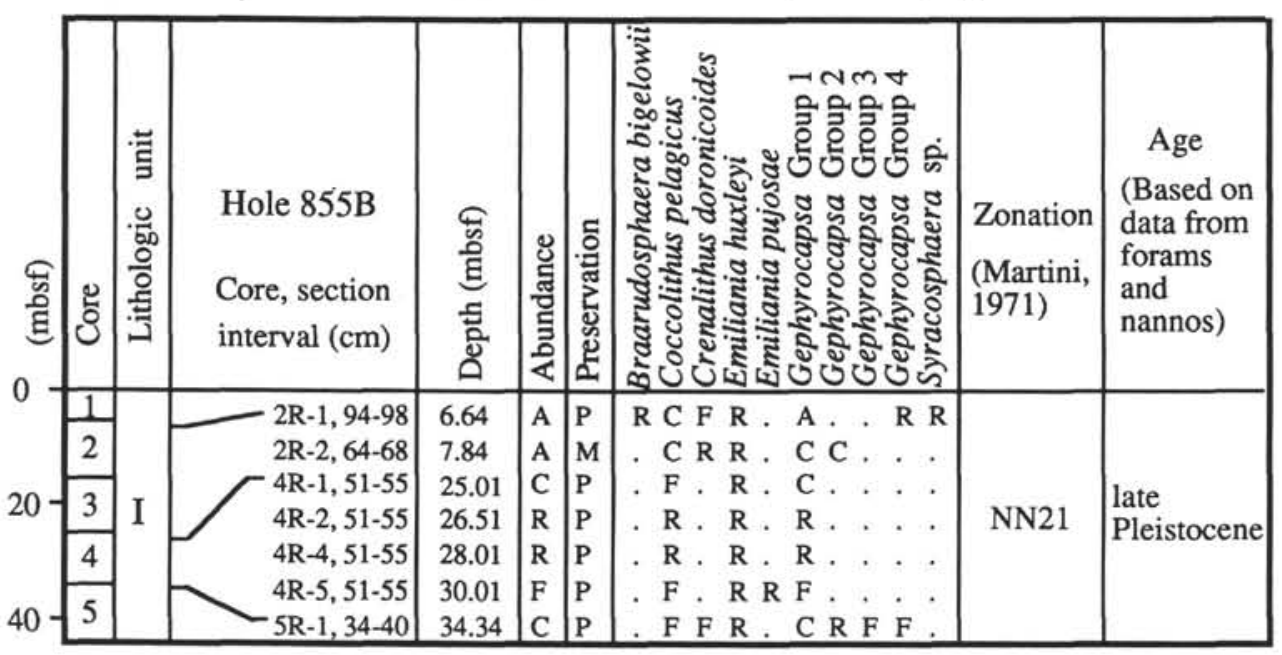

abundance ( 1 specimen/more than 50 fields in Sample 139-855A-9RCC). This species is rare in all seven samples from Hole 855B. In Hole $855 \mathrm{C} \mathrm{E}$. huxleyi is rare in most samples below Sample 139-855C-2R$6,84-88 \mathrm{~cm}$, and disappears from samples below Core 139-855C10R. In general, most of the section in Hole $855 \mathrm{C}$ and the whole section in Holes $855 \mathrm{~A}$ and $855 \mathrm{~B}$ can be assigned to the nannofossil $E$. huxleyi Zone (NN21) of Martini (1971). The absence of $E$. huxleyi in
Hole $855 \mathrm{C}$ from the bottom of Core $139-855 \mathrm{C}-11 \mathrm{R}$ may be the result of poor preservation.

Gartner (1977) defined the E. huxleyi Acme Zone by the dominance of $E$. huxleyi over the assemblage, suggesting that $E$. huxleyi is the most abundant species from this zone. Gard (1988) defined her Zone N-G1 as the interval from the Recent down to the point that Coccolithus pelagicus dramatically decreases in total abundance. Coc- 
Table 5. Distribution of calcareous nannofossils, Hole 855C, Leg 139.

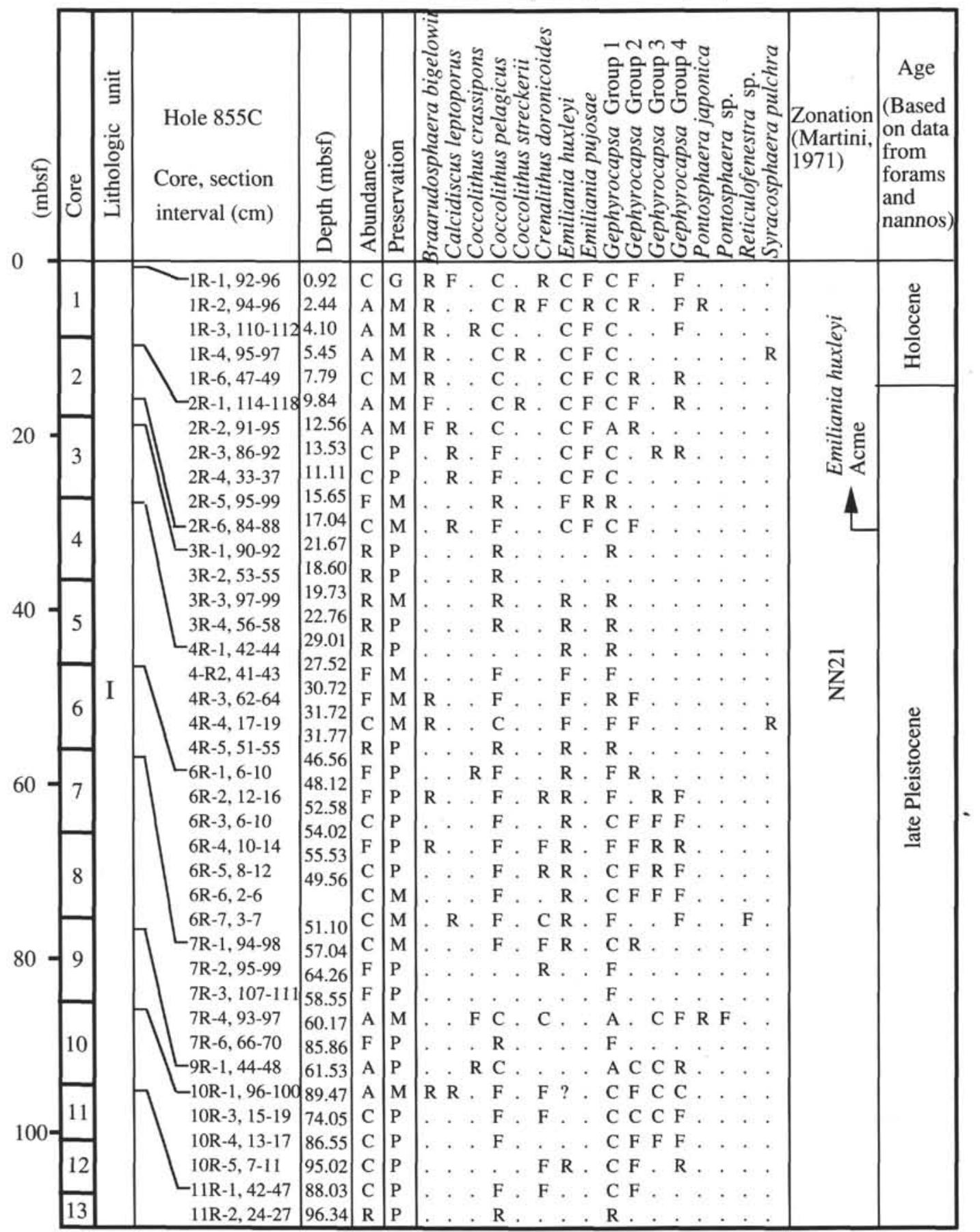

colithus pelagicus and $E$. huxleyi dominate the nannofossil assemblages in Zone N-G1, which lies within the E. huxleyi Acme Zone of Gartner (1977). Verbeek (1990), however, defined this acme zone (equal to his Zone NAN1) as the interval from the beginning of the acme of $E$. huxleyi to the Present without mentioning whether $E$. huxleyi dominates the nannofossil assemblages or not. In all samples investigated for this work except one (139-858A-2R-5, 6-10 cm), E. huxleyi never dominates Gephyrocapsa Group 1; instead, the latter is usually the most abundant form, even in the uppermost Holocene sediments. We also noticed that $E$. huxleyi increases its abundance distinctly from few-rare (1 specimen/several to some tens of fields of view) to common (2-9 specimens/field) at about 14-17 mbsf in Holes $855 \mathrm{~A}, 855 \mathrm{C}, 856 \mathrm{~A}$, and $857 \mathrm{~A}$. Therefore, we assume the base of the
E. huxleyi Acme Zone to be at $14.58 \mathrm{mbsf}$ in Hole $855 \mathrm{~A}$ and at 17.04 mbsf in Hole 855C.

Gephyrocapsa, as mentioned above, is the most abundant taxa and occurs in every sample from this site. Gephyrocapsa Group 1 (specimens 2.5-3.5 $\mu \mathrm{m}$ long) dominates the other three groups in Holes $855 \mathrm{~A}, 855 \mathrm{~B}$, and $855 \mathrm{C}$. This also supports the conclusions above based on $E$. huxleyi that the whole section from Site 855 can be assigned to Zone NN21 of Martini (1971).

\section{Site 856}

Situated over a small hill in the eastern part of Middle Valley (Fig. 1), Site 856 consist of eight holes at a water depth of $2406 \mathrm{~m}$ (Table 
2). The hill was formed by uplift of the sedimentary section above an intrusion associated with hydrothermal massive sulfide mineralization. Nannofossil investigations could be carried out on only two holes, 856A and 856B. In Hole 856A, more than half of the samples are barren of nannofossils (Table 1 and 6) while in Hole 856B, only one sample contains nannofossils.

The marker species, E. huxleyi, is common (2-10 specimens/ field) in samples from Hole 856A above $14.43 \mathrm{mbsf}$ (Sample 139-856A-3H$5,74-78 \mathrm{~cm}$ ) except where fossil preservation is poor. This depth ( $14.43 \mathrm{mbsf}$ ) is close to $14.58 \mathrm{mbsf}$ in Hole $855 \mathrm{~A}$, which we considered to be the base of the E. huxleyi Acme Zone; the same relationship possibly holds for Hole 856A. Emeliania huxleyi decreases in number markedly in three samples below $14.43 \mathrm{mbsf}$ and is absent from all samples below 21.54 mbsf (Sample 139-856A-3H-7, 34-38 cm), probably due to the poor preservation caused by hydrothermal activity.

Gephyrocapsa occurs in most samples above Sample 139-856A$6 \mathrm{H}-2,59-63 \mathrm{~cm}$ (above $41.14 \mathrm{mbsf}$ ) and is absent from all samples below this depth.

Gephyrocapsa Group 1 dominates the other three groups of the genus. One specimen of Helicosphaera inversa was encountered in Sample $139-856 \mathrm{~A}-3 \mathrm{H}-5,74-78 \mathrm{~cm}$. At Site 723 the last appearance datum (LAD) of $H$. inversa is stratigraphically higher than the first appearance datum (FAD) of E. huxleyi (Spaulding, 1991). Coccolithus pelagicus survived hydrothermal activities to the depth of $51.88 \mathrm{mbsf}$ and is the only species below 41.14 mbsf.

We assume that the section above $14.43 \mathrm{mbsf}$ in Hole $856 \mathrm{~A}$ as well as Core 139-856B-1H belongs to the E. huxleyi Acme Zone. Unfortunately, however, we cannot detect the base of Zone NN21 of Martini (1971) because poor preservation resulted in incomplete fossil records.

\section{Site 857}

Site 857 , at a water depth of $2433 \mathrm{~m}$ (Table 2), is located $1.5 \mathrm{~km}$ east of the sediment-buried fault that forms the current structural boundary of the central rift. The site lies over a major thermal anomaly, an area extending $10 \mathrm{~km}$ in a rift-parallel direction (Fig. 1). Two km north of the site is a hydrothermal vent field where heat flow exceeds $4 \mathrm{~W} / \mathrm{m}^{2}$ and fluids discharge at seafloor temperatures up to $276^{\circ}$. Four holes were drilled at this site, reaching the deepest depth in the study area (936 mbsf); however, the nannofossil investigation focused on two holes only, 857A and $857 \mathrm{C}$. Both fossil abundance and species diversity are generally higher in Hole 857A than in Hole 857C (Tables 7 and 8). Despite the deep depth of the latter (519.4 mbsf), nannofossils were encountered mostly above $145.63 \mathrm{mbsf}$ (Sample 139-857C-13R$1,76-80 \mathrm{~cm})$

In Hole 857A, Emiliania huxleyi was found in most of samples above $73.93 \mathrm{mbsf}$ (Sample 139-857 A-9H-4, 3-7 cm) but is common (2-5 specimens/field) only in samples above $17.68 \mathrm{mbsf}$ (Sample 139-857 A-2H-5, $28 \mathrm{~cm}$ ), except where preservation is either poor or general fossil abundance decreases. For the same reason discussed above, we consider this depth ( $17.68 \mathrm{mbsf})$ to be the base of the $E$. huxleyi Acme Zone. The first occurrence of E. huxleyi in Sample $139-857 \mathrm{~A}-9 \mathrm{H}-4,3-7 \mathrm{~cm}$ indicates that the section above this point can be assigned to Zone NN21 of Martini (1971). The section below, however, cannot be assigned to any zone due to the lack of marker species, probably due to poor preservation. Group 1 Gephyrocapsa in the lower section of Hole 857A, which dominates the other three groups of the genus, supports the conclusion that the whole section of Hole 857 A belongs to Zone NN21. The first occurrence of $E$. huxleyi in Hole 857C (Sample 139-857C-12R-2, 63-66 cm) is not entirely reliable because $E$. huxleyi was encountered so rarely ( $2-3$ specimens/100 fields) under the light microscope that it cannot be verified by SEM. Coccolithus pelagicus is practically the only species in assemblages from samples immediately below the disappearance of
E. huxleyi; fossil preservation in these samples is also poor to very poor. Therefore, it is difficult to draw any conclusions on the zonation of the lower $364 \mathrm{~m}$ of section at Site 857C.

\section{Site 858}

Site 858 lies over an active hydrothermal vent field that extends several hundred meters along and across the strike of Middle Valley (Fig. 1). Heat flow measured in the vent field ranges from $4 \mathrm{~W} / \mathrm{m}^{2}$ to $20 \mathrm{~W} / \mathrm{m}^{2}$ (Davis, Mottl, Fisher, et al,, 1992). Located $1.8 \mathrm{~km}$ north of Site 857 , the regional structural setting of Site 858 is similar to that at Site 857. Although seven holes were drilled at this site, sampling for calcareous nannofossils was restricted to four holes (858A, 858B, $858 \mathrm{C}$, and $858 \mathrm{D})$.

Calcareous nannofossils were found only near the top of the section and in less than half of the core sections in these holes; preservation is generally poor to very poor owing to high-temperature hydrothermal diagenesis. As at the other sites, Gephyrocapsa, Coccolithus pelagicus, and Emiliania huxleyi are the main taxa in most fossiliferous samples, particularly in the former two holes (Tables 9 and 10). The latter usually occurs in the uppermost samples. However, the E. huxleyi Acme Zone is difficult to detect, apparently because thermal activity destroyed part or all of the nannofossil assemblages.

Hole 858A has the most abundant and diverse assemblages among the four holes. Fossiliferous samples in this hole reach $81.7 \mathrm{mbsf}$ (Table 9), but only the uppermost section (above $20 \mathrm{mbsf}$ ) can be assigned with certainty to Zone NN21 of Martini (1971) based on the occurrence of E. huxleyi. Most of the fossiliferous section may still fall within Zone NN21 as suggested by the dominance of Gephyrocapsa Group 1 . The high heat flow that apparently destroyed the nannofossil assemblages at this site strongly hampered our biostratigraphic studies.

\section{Estimated Sedimentation Rates During the Last 73 k.y.}

The Emiliania huxleyi Acme Zone was tentatively recognized in Holes 855A (14.58 mbsf), 855C (17.04 mbsf), 856A (14.43 mbsf), and $857 \mathrm{~A}$ (17.68 mbsf). Sedimentation rates can be obtained based on the chronology of the acme zone (73 k.y. for high latitudes according to Verbeek, 1990). As we calculated for Hole 857A in Davis, Mottl, Fisher, et al. (1992), the sedimentation rates for these holes are as follows:

Hole 855A: $24 \mathrm{~cm} / \mathrm{ky}$; Hole 855C: $23 \mathrm{~cm} / \mathrm{k}$.y.; and Hole 856A: 23 $\mathrm{cm} / \mathrm{k}$.y. Thus, the sedimentation rates in the study area range from 20 $\mathrm{cm} / \mathrm{k} . \mathrm{y}$. (minimum) to $27 \mathrm{~cm} / \mathrm{k} . \mathrm{y}$. (maximum).

\section{FOSSIL PRESERVATION/HYDROTHERMAL ALTERATION}

McIntyre and McIntyre (1971), Roth and Berger (1975), and Schneidermann (1977) studied the dissolution of Recent calcareous nannofossils in the Indian and Atlantic Oceans. They stated that all coccoliths would be dissolved below the calcium carbonate compensation depth (CCD) and that the skeletal ultrastructure of nannofossils is mainly responsible for the dissolution susceptibility of each species. For example, holococcoliths are readily dissolved while placoliths are highly resistant to solution. Not only is dissolution species selective, but within a single coccolith specimen, selective removal of skeletal elements proceeds in an orderly sequence (Wise, 1977). These conclusions are valid worldwide.

In the study area the water depths of all holes are about 2400-2450 $\mathrm{m}$ (Table 2), much shallower than the $\mathrm{CCD}$, which lies at depths of about $4500 \mathrm{~m}$ in the equatorial Pacific (Bramlette, 1961) and at about $5500 \mathrm{~m}$ in the Atlantic (Turekian, 1965). It seems, therefore, that the poor preservation of calcareous nannofossils in the study area resulted mostly from in-situ hydrothermal activity rather than dissolu- 
Table 6. Distribution of calcareous nannofossils, Hole 856A, Leg 139.

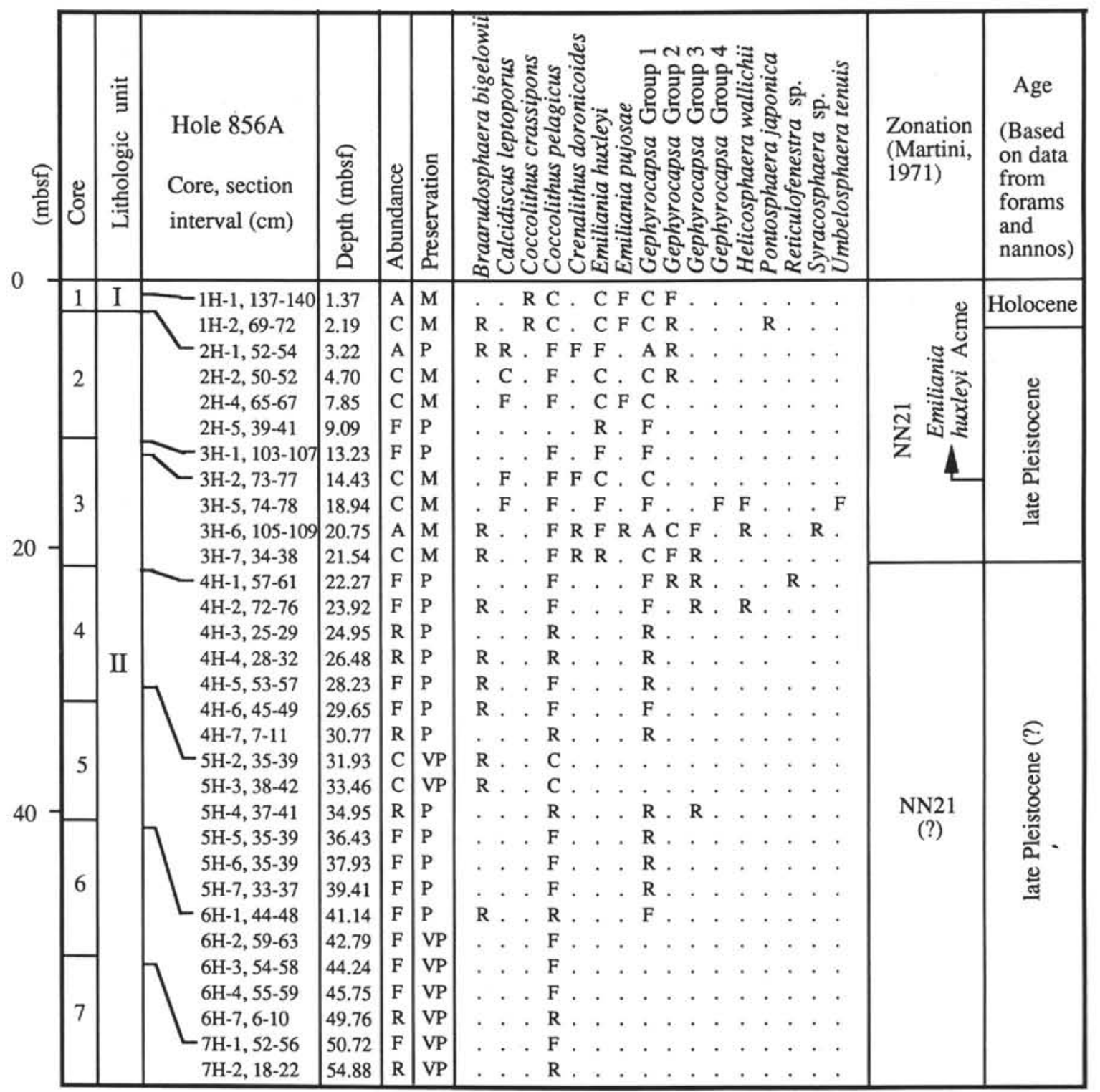

tion at depth in the water column. Hydrothermal fluids may contain hot chemical components and gas, which can partially or completely dissolve or destroy fossils and alter the composition of assemblages.

Figure 2 illustrates the lowest sub-bottom depths at which fossiliferous samples and the first occurrences of Emiliania huxleyi are found in the different holes. These two depths vary markedly from hole to hole although there is no indication that all biostratigraphic datums vary in a similar fashion. For instance, in Holes $855 \mathrm{~B}, 855 \mathrm{C}$, and $857 \mathrm{~A}$, the $E$. huxleyi Acme datum is found at between 15 and 18 mbsf (Fig. 2), but the first occurrence of E. huxleyi varies strongly and unpredictably below 21.7 and 101.5 mbsf.

Also plotted against depth in Figure 2 are paleotemperatures inferred from studies of color changes in palynomorphs and from vitrinite reflectance. The depths of these paleotemperature indicators, which increase downhole from $<60^{\circ} \mathrm{C}$ to $<200^{\circ} \mathrm{C}$, also vary widely from hole to hole. These high-temperature readings are attributed to heat flow associated with hydrothermal activity (Mao et al., this volume).
There is a clear tendency for the first $E$. huxleyi and the first nannofossil datums in Figure 2 to occur at shallower depths in holes where heat flows are or have been high and deeper in holes where heat flows have been low. For example, note the sharp differences between Sites 857 and 858 and between Holes $858 \mathrm{~A}$ (about $100 \mathrm{~m}$ west of the hydrothermal vent field) and $858 \mathrm{~B}$ (a few meters away from a $276^{\circ} \mathrm{C}$ hydrothermal vent; Davis, Mottl, Fisher, et al., 1992). The shallow depths of the two nannofossil indicators in question in Hole 856A suggest that the heat flow was about as high there when the vent was active sometime in the past as it is now in Hole 858A even though the measured heat flow from Hole $856 \mathrm{~A}$ at present is relatively low at only $0.60 \mathrm{~W} / \mathrm{m}^{2}$ (Davis, Mottl, Fisher, et al., 1992). This is much lower than that in Hole 858A, and even lower than that in Hole 857A $\left(0.71 \mathrm{~W} / \mathrm{m}^{2}\right.$; see Davis, Mottl, Fisher, et al., 1992).

The distance between the first $E$. huxleyi and the first nannofossils should reflect the hydrothermal temperature gradient. The shorter the distance, the steeper the gradient (as in Holes 858B, 858C, and 858D); 
Table 7. Distribution of calcareous nannofossils, Hole 857A, Leg 139.

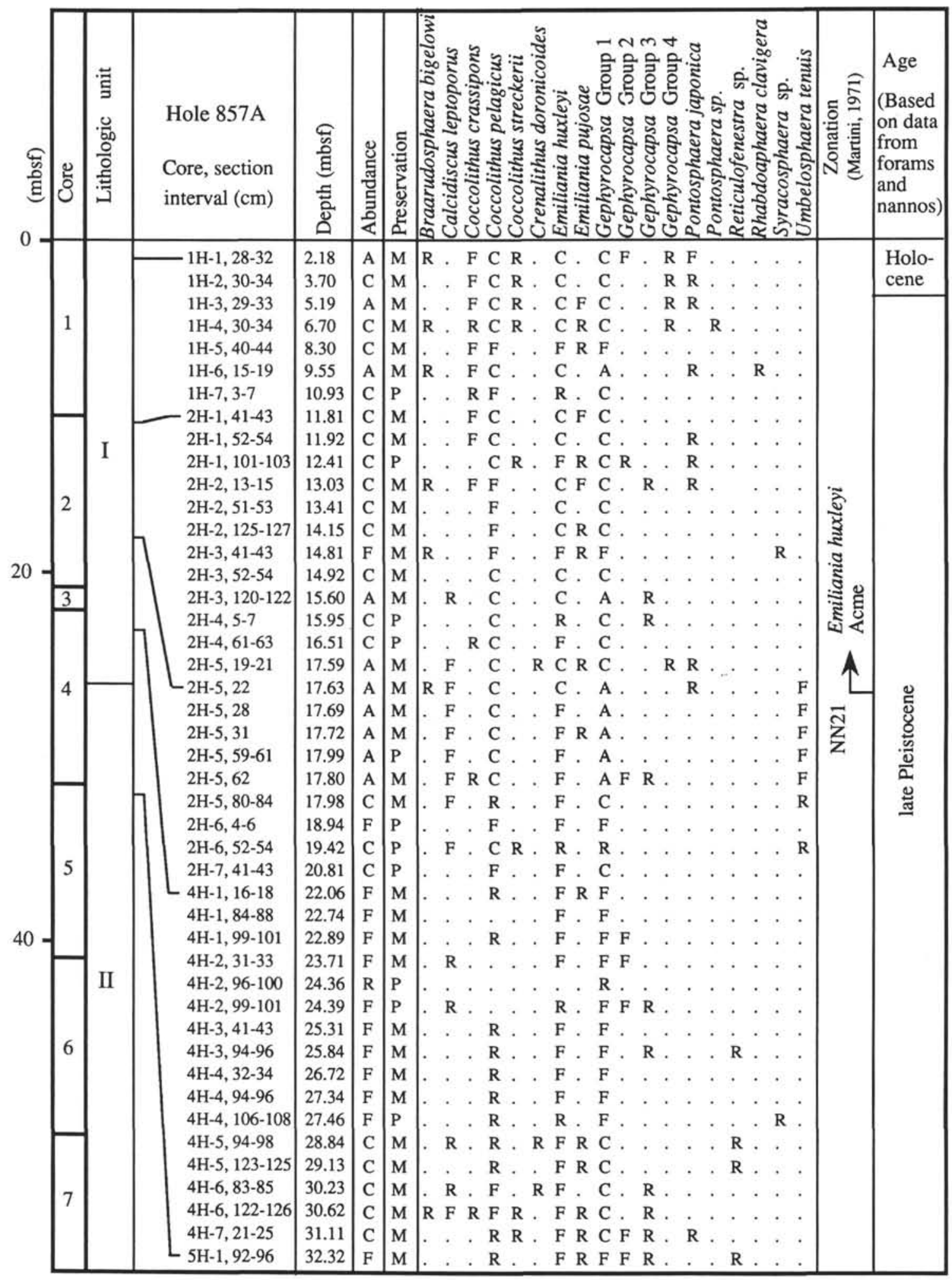

the greater the distance, the shallower the gradient (as in Hole 857C). At Site 855, the depths of the first stratigraphic occurrence of Emiliania huxleyi in the three holes is apparently not the first evolutionary occurrence of this species; we believe the holes were not drilled deep enough to reach that datum. The greatest distance between the two datums in question occurs in Hole $857 \mathrm{C}$. This suggests that hydrother- mal discharges occurred much deeper here and did not permeate as much of the section. The hydrothermal fluids at this location were probably diverted laterally at depth and discharged in nearby vent fields.

In summary, the nannofossils recorded either earlier or current hydrothermal activity, and in general their state of preservation indicates the intensity of that activity (Fig. 2). The higher the thermal temperature at 
Table 7 (continued).

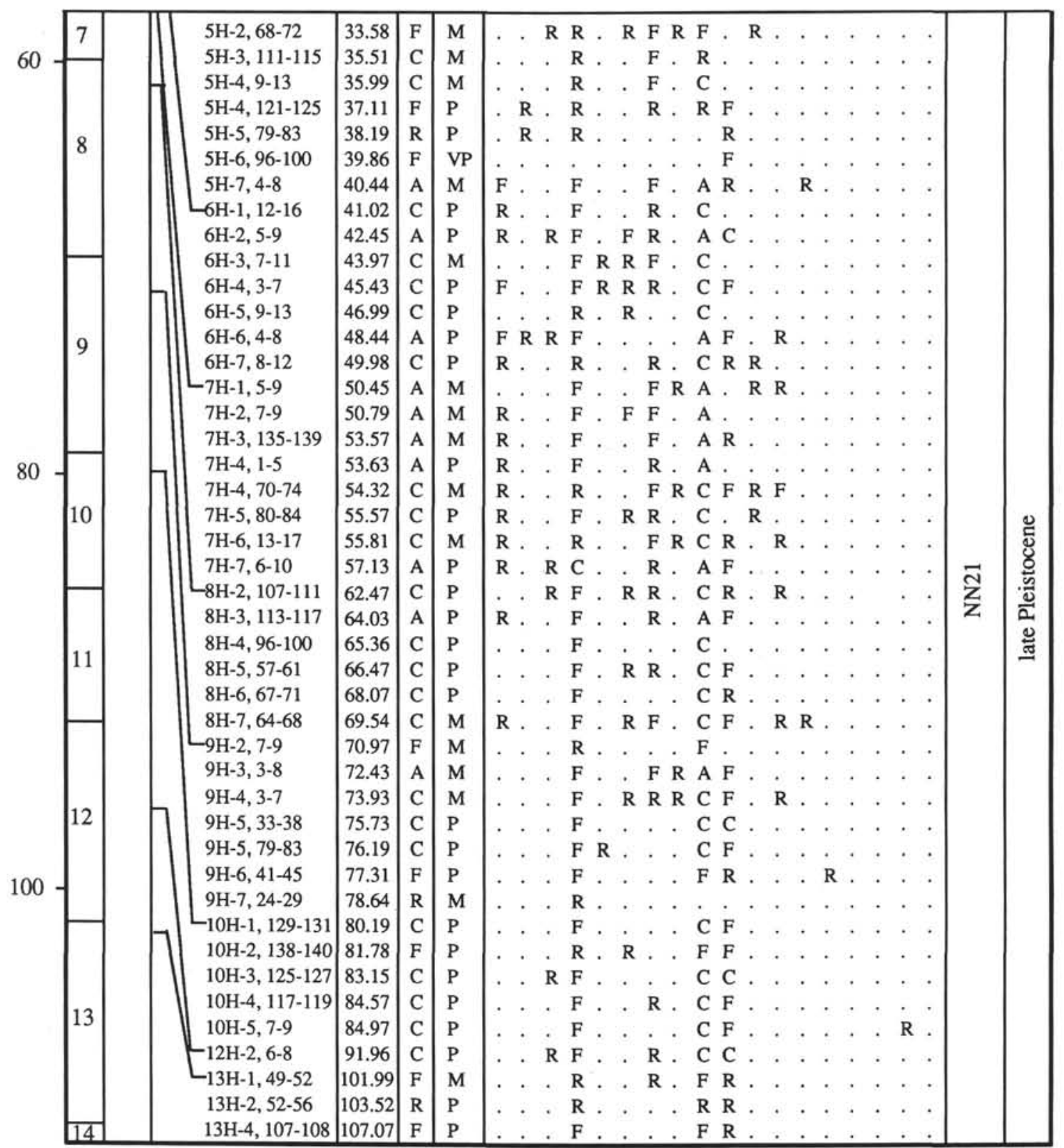

the various sites, the more intense the activity and the poorer the fossil preservation. Because this is an irreversible process, we can detect past hydrothermal activity by investigating nannofossil preservation.

There is also a selective dissolution of individual taxa in response to the hydrothermal activity, which functions much like that caused by dissolution at depth in the oceans near the CCD. Among the placoliths, Emiliania huxleyi is less resistant to thermal and fluid corrosion in comparison to Coccolithus pelagicus, possibly due to its delicate "T"-shaped elements (Plate 4, Figs. 3, 5, 7, and 10). It disappears in some holes at shallow sub-bottom depths. For example, it disappears abruptly where its abundance is common in Hole 858B (Figure 2); there the heat flow is high (a temperature of $197^{\circ} \mathrm{C}$ was measured with the WSTP at 19.5 mbsf [see Davis, Mottl, Fisher, et al., 1992]). The more widespread occurrence of Gephyrocapsa at relatively deeper sub-bottom depths (e.g., Sample 139-857C-30R-3, 85-88 cm, 316.95 mbsf) and from sediments suffering relatively high temperatures (e.g., Sample 139-856A-6R-1, 44-48 cm, with an estimated temperature lower than $120^{\circ} \mathrm{C}$ [see Mao et al., this volume]) suggests that Gephyrocapsa is more resistant to hydrothermal activity than Emiliania.

In Gephyrocapsa the loss of the central bridge is sometimes the first stage of dissolution caused by corrosion or thermal alteration (Plate 2, Figs. 5, 6, 8, and 9; Plate 3, Figs. 1, 2, and 3). If hydrothermal activity intensifies, the elements that form the two shields are dissolved bit by bit and separated from each other (Plate 2, Figs. 1, 2, 4, and 7). In some cases, these elements may be heavily corroded and overgrown to form two reinforced shields (Plate 2, Fig. 8). An extreme situation is noted deep in Hole $855 \mathrm{C}$, where spike-like overgrowths project from the outer ends of the elements of both shields (Plate 2, Fig. 9); whether or not these are calcite overgrowths has not been determined.

Coccolithus pelagicus is apparently the most resistant taxon to hydrothermal activity, as evidenced by its occurrences at the deepest depths (e.g., Sample 139-857C-44R-2, 105-109 cm, 392.23 mbsf) and in zones that experienced high temperatures (e.g., the deepest samples from Holes 856A and 858B; Tables 6 and 10). During the initial stages 


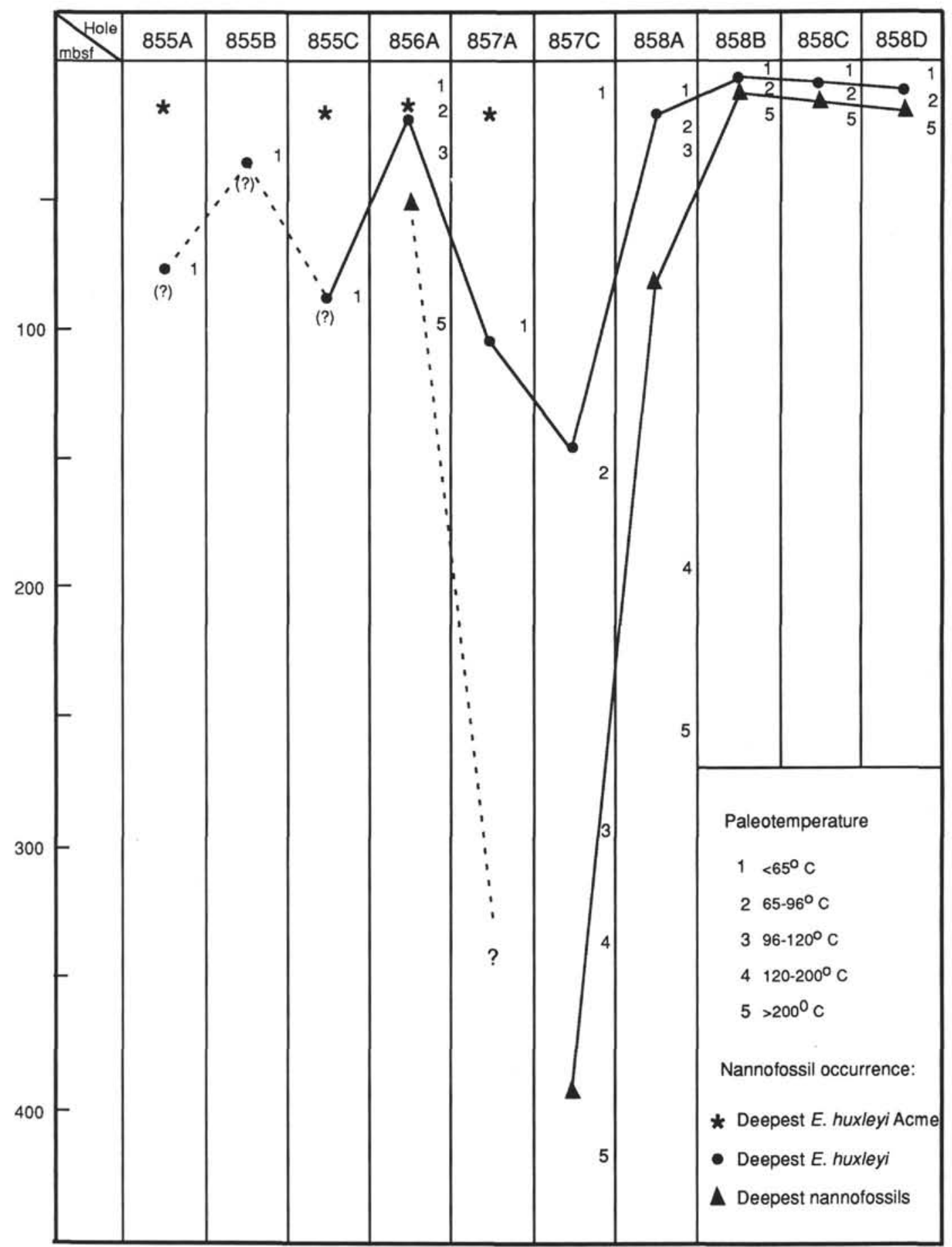

Figure 2. Sub-bottom depths at which the deepest (first) calcareous nannofossils (solid triangles), Emiliania huxleyi (solid circles), and E. huxleyi Acme (asterisks) occur in Leg 139 holes. Paleotemperatures given in the figure are from Mao et al. (this volume).

of dissolution, the laths forming the two shields of $C$. pelagicus may be partially dissolved (Plate 1, Fig. 9), then subsequently have calcite reprecipitated (Plate 3, Figs. 8, 9; Plate 4, Fig. 1). Ultimately, the coccolith may be transformed into two integrated shields in which individual laths are strongly obscured (Plate 4, Fig. 9). As in the case of Gephyrocapsa noted previously, only the wavy or rugged edge of the shield may remain visible to suggest the identity of the taxon.

As noted by Wise (1973), the proximal shield elements of Coccolithus are the most susceptible to dissolution, often leaving only the distal shield preserved (Plate 1, Fig. 6). Calcidiscus leptoporus displays a similar dissolution phenomenon (Plate 1, Fig. 5).

The dissolution susceptibility of nannofossils subjected to hydrothermal activity in our study area approximates reasonably well that determined empirically for Recent coccoliths in the tropical and extratropical Pacific Ocean by Roth and Berger (1975). These authors found Emiliania huxleyi to be less resistant to dissolution than species of Gephyrocapsa or Coccolithus except for the minute Gephyrocapsa ericsonii in tropical areas. They also found that Coccolithus pelagi- 
Table 8. Distribution of calcareous nannofossils, Hole 857C, Leg 139.

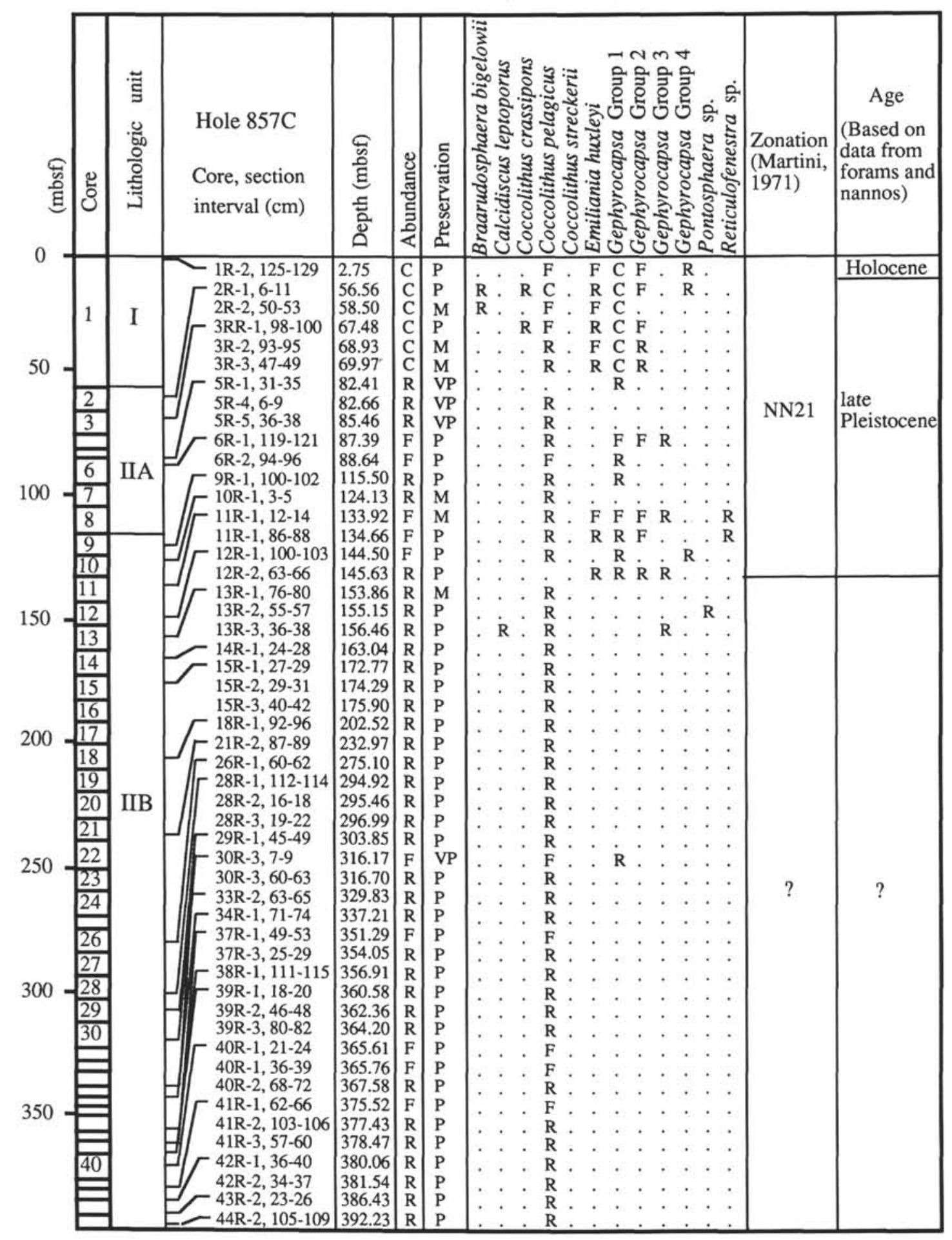

cus was more resistant to dissolution than the cool-water tolerant Gephyrocapsa, which are the dominant forms found in our study area.

Mixed assemblages that display different states of preservation are quite common in our study area, perhaps due to redeposition of nannofossils from shallow environments along with fine-grained clastic turbidites, which constitute one of the dominant lithologies in the study area. Without this complication, we would have expected to detect a more systematic ranking of hydrothermal alterations among the nannofossil assemblages. In general, however, the preservational state of the nannofossils, if used in conjunction with other methods of paleothermometry, can still be used as a tracer of hydrothermal history.

\section{SUMMARY}

Upper Quaternary calcareous nannofossils have been investigated from Leg 139 drill cores from the heavily sedimented Middle Valley of the northern Juan de Fuca Ridge in the northeast Pacific Ocean. The host sediments have been subjected at depth to high temperatures and 
Table 9. Distribution of calcareous nannofossils, Hole 858A, Leg 139.

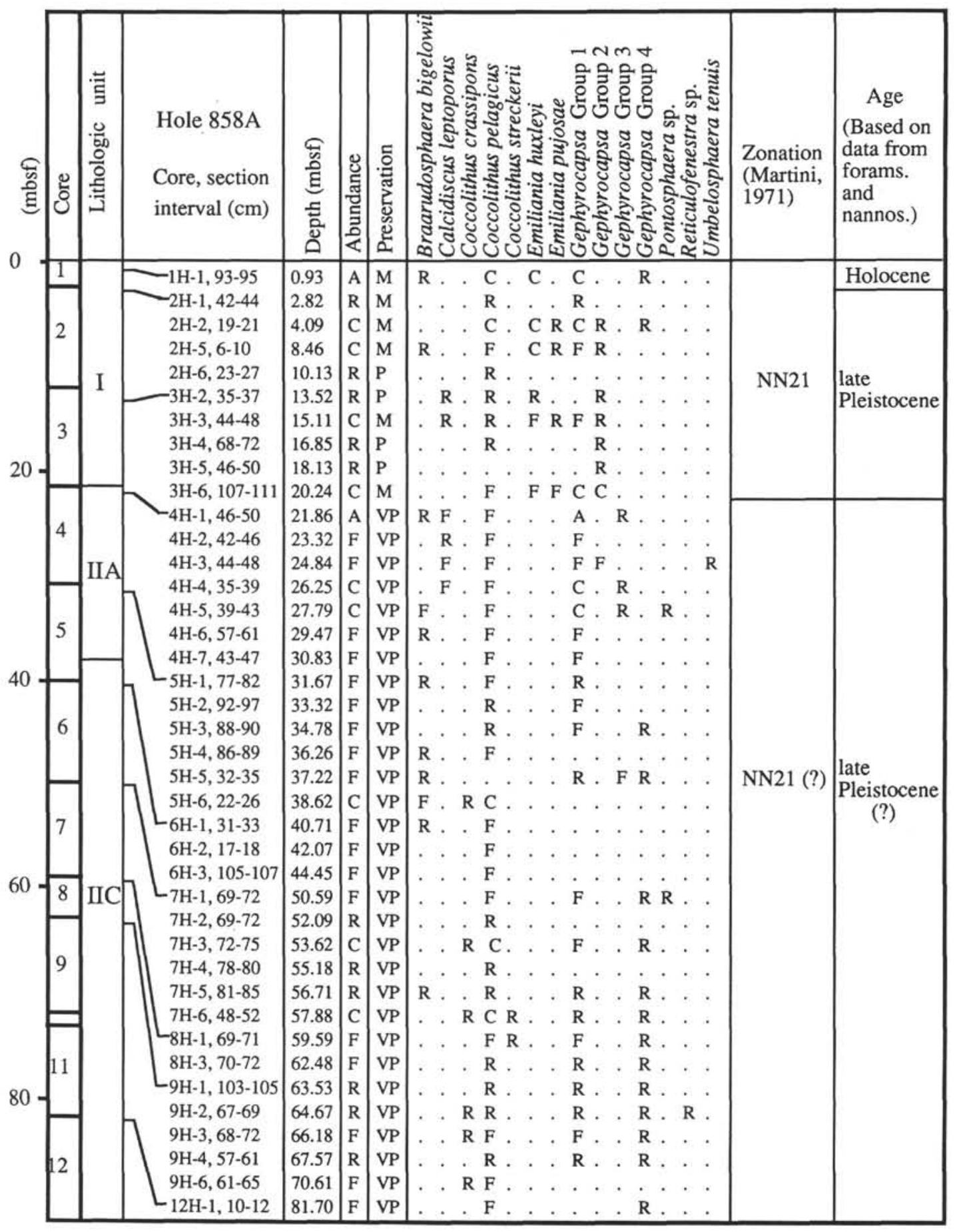

hot hydrothermal fluids that have altered or destroyed in part or in toto the nannofossil assemblages, thereby raising at several sites the level of the first (deepest) stratigraphic occurrence of nannofossils or of the important Emiliania huxleyi datum. The degree of alteration of the nannofossil assemblages is dependent on the intensity of the heat and/or hydrothermal activity, which are indicated by paleotemperatures derived independently from studies of color alteration of palynomorphs and by vitrinite reflectance (Mao et al., this volume). State of preservation and the downhole level at which assemblages have been destroyed correlate well with the inferred paleotemperature estimates. Destruction of the assemblages appears to be species selective, and follows in general the dissolution rankings determined independently by others for Recent nannofossils of the Pacific basin. More systematic correlation of these phenomena are hampered, however, by the fact that nannofossil preservation is already quite variable at the time of deposition because of the predominance of turbidite activity in the study area.

\section{ACKNOWLEDGMENTS}

We thank Drs. Eric de Kaenel and Wuchang Wei for reviewing critical slides, for their helpful discussion, and for their reviews of the 
Table 10. Distribution of calcareous nannofossils, Holes 858B, 858C, and 858D, Leg 139.

\section{Hole 858B}
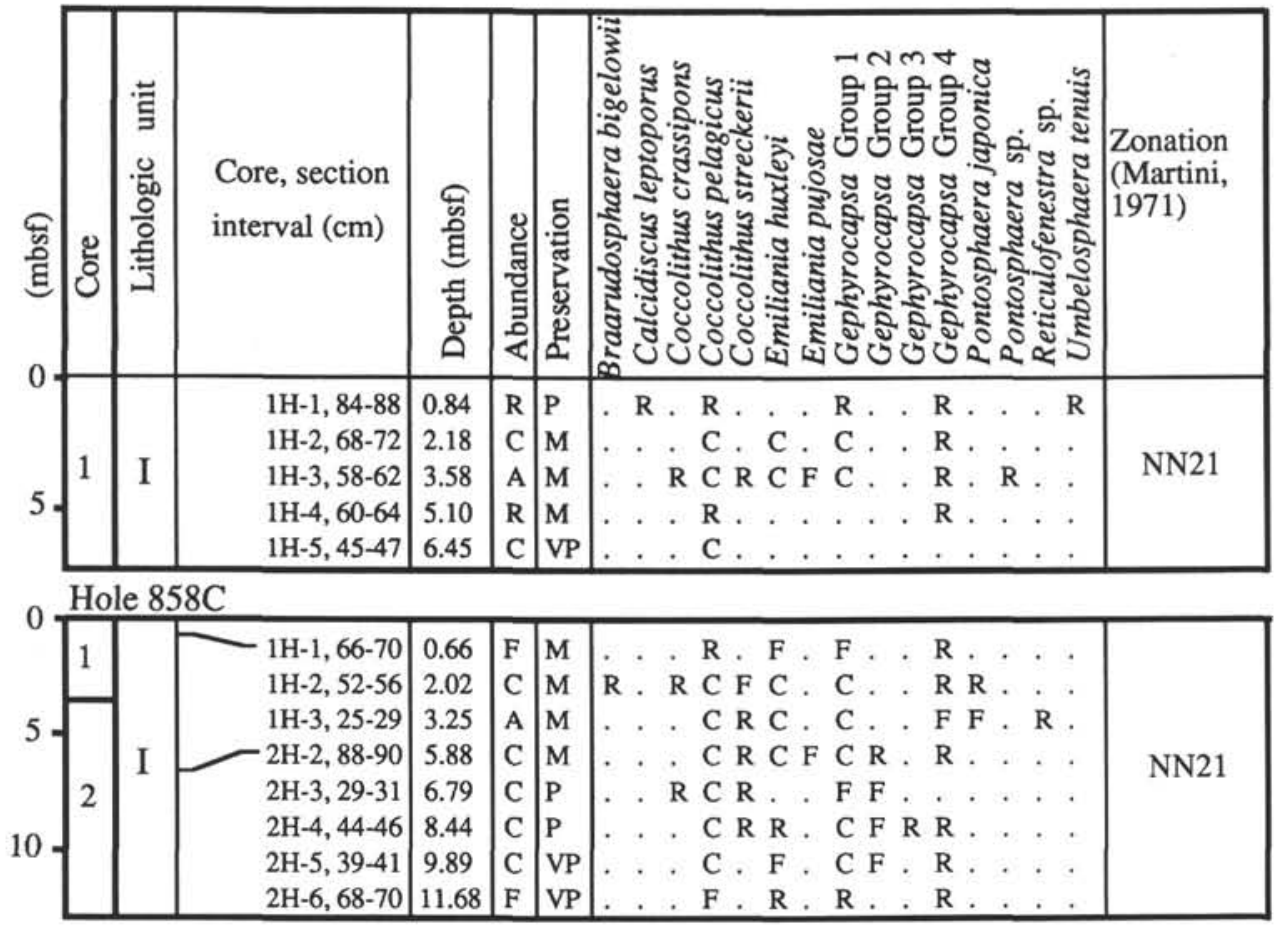

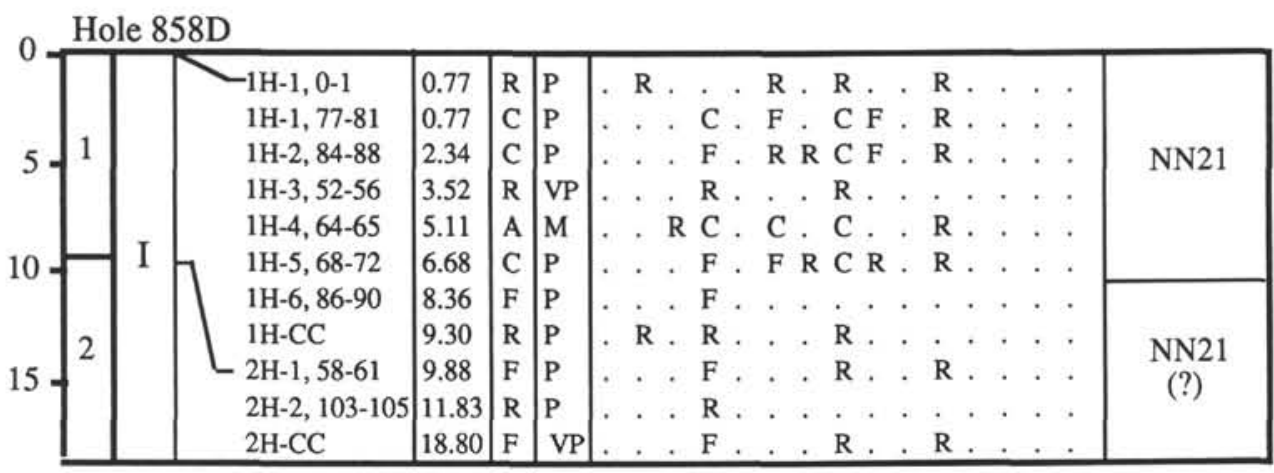

manuscript. Smear slides were made by Ms. Xinlan Liu, Li Liu, and Kimberley Hall; Li Liu also helped prepare tables in the text. The SEM was skillfully operated by Ms. Kim Riddle. The study was supported by USSAC funds; NSF grant DPP 91-18480 provided necessary laboratory facilities.

\section{REFERENCES}

Berggren, W.A., Kent, D.V., and Van Couvering, J.A., 1985. The Neogene: Part 2. Neogene geochronology and chronostratigraphy. In Snelling, N.J. (Ed.), The Chronology of the Geological Record. Geol. Soc. London Mem., 10:211-260.

Bramlette, M.N., 1961. Pelagic sediments. In Sears, M. (Ed.), Oceanography Am. Assoc. Adv. Sci. Publ., 67:345-366.

Davis, E.E., Mottl, M.J., Fisher, A.T., et al., 1992. Proc. ODP, Init. Repts., 139: College Station, TX (Ocean Drilling Program).

-Abbreviations for names of organizations and publications in ODP reference lists follow the style given in Chemical Abstracts Service Source Index (published by American Chemical Society).
Gard, G., 1988. Late Quaternary calcareous nannofossil biozonation, chronology and paleo-oceanography in areas north of the Faeroe-Iceland Ridge. Quat. Sci. Rev., 7:65-78.

Gard, G., and Backman, J., 1990. Synthesis of Arctic and Subarctic coccolith biochronology and history of North Atlantic drift water influx during the last 500,000 years. In Bleil, U., et al. (Eds.), Geologic History of the Polar Oceans: Arctic versus Antarctic. NATO ASI Ser., Ser. C., 417-436.

Gartner, S., 1977. Calcareous nannofossil biostratigraphy and revised zonation of the Pleistocene. Mar. Micropaleontol., 2:1-25.

Martini, E., 1971. Standard Tertiary and Quaternary calcareous nannoplankton zonation. In Farinacci, A. (Ed.), Proc. 2nd Int. Conf. Planktonic Microfossils Roma: Rome (Ed. Tecnosci.), 2:739-785.

Matsuoka, H., and Okada, H., 1989. Quantitative analysis of Quaternary nannoplankton in the subtropical northwestern Pacific Ocean. Mar. Micropaleontol., 14:97-118.

1990. Time-progressive morphometric changes of the genus Gephyrocapsa in the Quaternary sequence of the tropical Indian Ocean. In Duncan, R.A., Backman, J., Peterson, L.C., et al., Proc. ODP, Sci. Results, 115: College Station, TX (Ocean Drilling Program), 255-270.

McIntyre, A., and McIntyre, R., 1971. Coccolith concentrations and differential solution in oceanic sediments. In Funnel, B.M., and Riedel, W.R. (Eds.), The Micropaleontology of Oceans: London (Cambridge Univ. Press), 253-261. 
Perch-Nielsen, K., 1985. Cenozoic calcareous nannofossils. In Bolli, H.M., Saunders, J.B., and Perch-Nielsen, K. (Eds.), Plankton Stratigraphy: Cambridge (Cambridge Univ. Press), 427-554.

Rio, D., 1982. The fossil distribution of coccolithophore genus Gephyrocapsa Kamptner and related Plio-Pleistocene chronostratigraphic problems. In Prell, W.L., Gardner, J.V., et al., Init. Repts. DSDP, 68: Washington (U.S. Govt. Printing Office), 325-343.

Rio, D., Raffi, I., and Villa, G., 1990. Pliocene-Pleistocene calcareous nannofossil distribution patterns in the Western Mediterranean. In Kastens, K.A., Mascle, J., et al., Proc. ODP, Sci. Results, 107: College Station, TX (Ocean Drilling Program), 513-533.

Roth, P.H., and Berger, W.H., 1975. Distribution and dissolution of coccoliths in the south and central Pacific. In Sliter, W.V., Bé, A.W.H., and Berger, W.H. (Eds.), Dissolution of Deep-Sea Carbonates. Spec. Publ. Cushman Found. Foraminiferal Res., 13:87-113.

Sato, T., Kameo, K., and Takayama, T., 1991. Coccolith biostratigraphy of the Arabian Sea. In Prell, W.L., Niitsuma, N., et al., Proc. ODP, Sci. Results, 117: College Station, TX (Ocean Drilling Program), 37-54.

Schneidermann, N., 1977. Selective dissolution of Recent coccoliths in the Atlantic Ocean. In Ramsay, A.T.S. (Ed.), Oceanic Micropaleontology: New York (Academic Press), 1009-1053.

Spaulding, S., 1991. Neogene nannofossil biostratigraphy of Sites 723 through 730, Oman Continental Margin, northwestern Arabian Sea. In Prell, W.L., Niitsuma, N., et al., Proc. ODP, Sci. Results, 117: College Station, TX (Ocean Drilling Program), 5-36.

Takayama, T., and Sato, T., 1987. Coccolith biostratigraphy of the North Atlantic Ocean, Deep Sea Drilling Project Leg 94. In Ruddiman, W.F., Kidd, R.B., Thomas, E., et al., Init. Repts. DSDP, 94 (Pt. 2): Washington (U.S. Govt. Printing Office), 651-702.

Turekian, K.K., 1965. Some aspects of the geochemistry of marine sediments. In Riley, J.P., and Skirrow, G. (Eds.), Chemical Oceanography: New York (Academic Press), 2:81-126.

Verbeek, J.W., 1990. Late Quaternary calcareous nannoplankton biostratigraphy for the Northern Atlantic Ocean. Meded. Rijks Geol. Dienst, 44:14-33.

Wise, S.W., Jr., 1973. Calcareous nannofossils from cores recovered during Leg 18, Deep Sea Drilling Project: biostratigraphy and observations of diagenesis. In Kulm, L.D., von Huene, R., et al., Init. Repts. DSDP, 18: Washington (U.S. Govt. Printing Office), 569-615.
1977. Chalk formation: early diagenesis. In Anderson, N.R., and Malahoff, A. (Eds.), The Fate of Fossil Fuel $\mathrm{CO}_{2}$ in the Oceans: New York (Plenum), 717-739.

\section{Date of initial receipt: 29 March 1993 \\ Date of acceptance: 22 October 1993 \\ Ms 139SR-208}

\section{APPENDIX}

Calcareous nannofossils encountered in alphabetical order of generic epithets (for bibliographic references, see Perch-Nielsen, 1985).

Braarudosphaera bigelowii (Gran and Braarud, 1935) Deflandre, 1947

Calcidiscus leptoporus (Murray and Blackman, 1898) Loeblich and Tappan, 1978

Coccolithus crassipons Bouché, 1962

Coccolithus pelagicus (Wallich, 1877) Schiller, 1930

Coccolithus streckerii Takayama and Sato, 1987

Crenalithus doronicoides (Black and Barnes, 1961) Roth, 1973

Emiliania huxleyi (Lohmann, 1902) Hay and Mohler in Hay et al., 1967

Emiliania pujosae Verbeek, 1990

Gephyrocapsa Group 1, this paper (modified from Gard, 1988)

Gephyrocapsa Group 2, Gard, 1988

Gephyrocapsa Group 3, Gard, 1988

Gephyrocapsa Group 4, this paper

Helicosphaera inversa Gartner, 1980

Helicosphaera kamptneri Hay and Mohler in Hay et al., 1967

Helicosphaera wallichii (Lohmann, 1902) Boudreaux and Hay, 1969

Pontosphaera japonica (Takayama, 1967) Nishida, 1971

Pontosphaera sp.

Reticulofenestra sp.

Syracosphaera pulchra Lohmann, 1902

Syracosphaera sp.

Umbellosphaera tenuis (Kamptner, 1937) Paasche in Markali and Paasche, 1955 


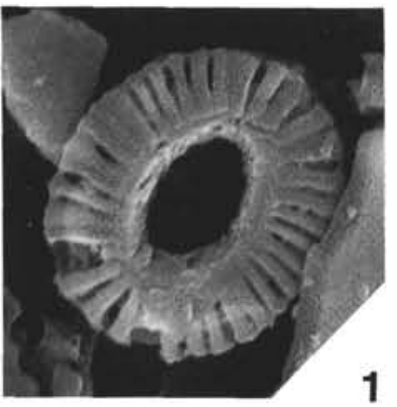

$\overline{1 \mu \mathrm{m}}$

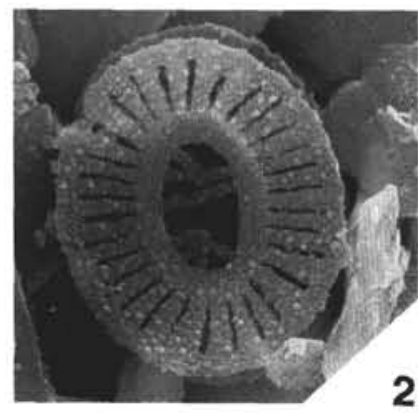

$1 \mu \mathrm{m}$

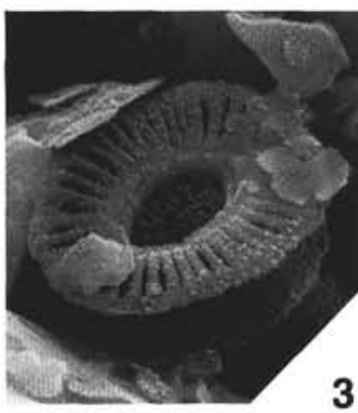

$1 \mu \mathrm{m}$

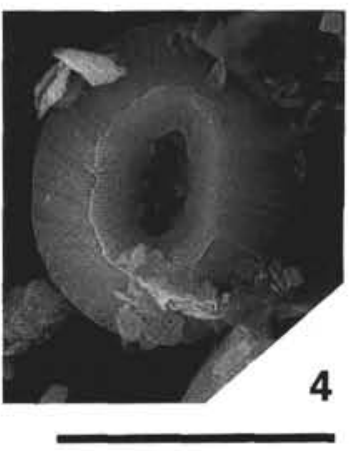

$1 \mu \mathrm{m}$

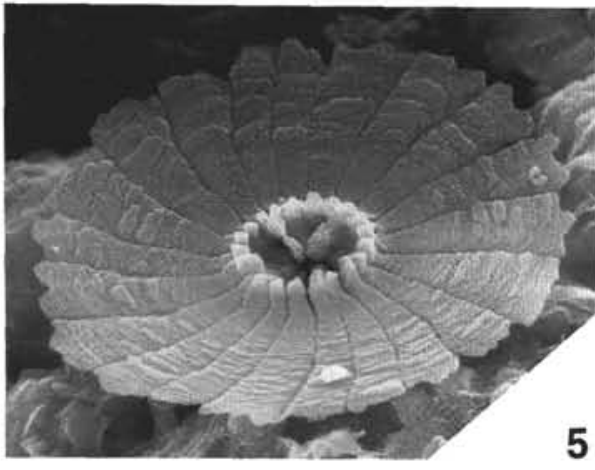

$1 \mu \mathrm{m}$

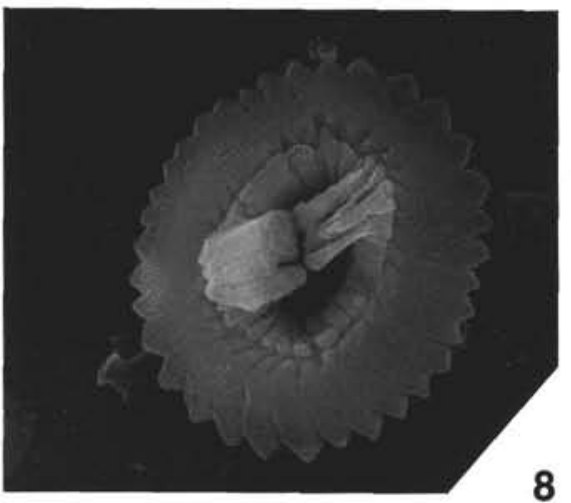

$1 \mu \mathrm{m}$

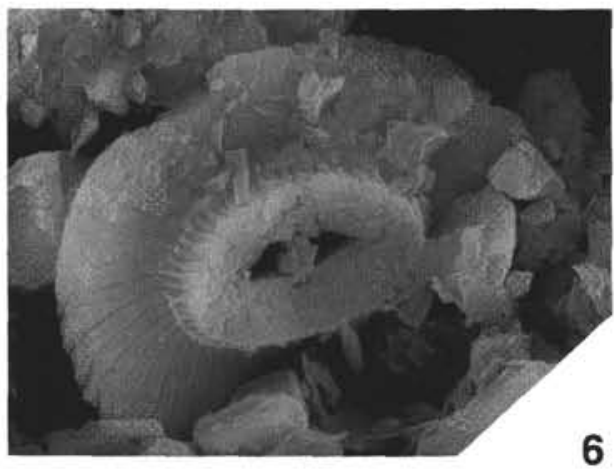

$1 \overline{\mu m}$

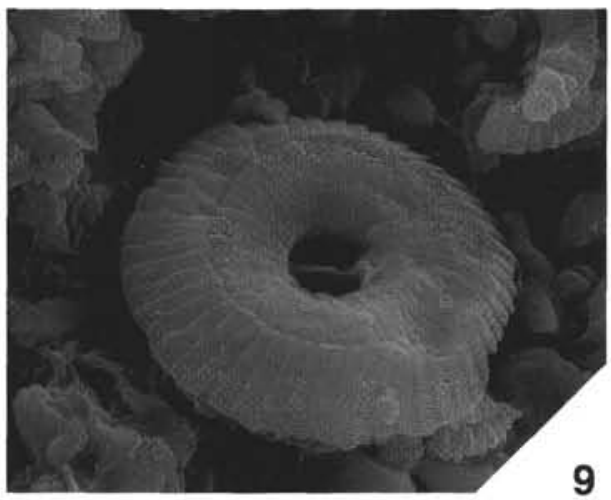

$1 \mu \mathrm{m}$

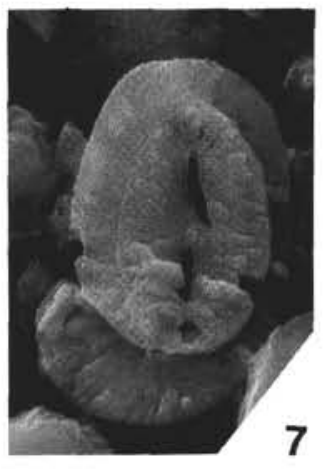

$1 \mu \mathrm{m}$

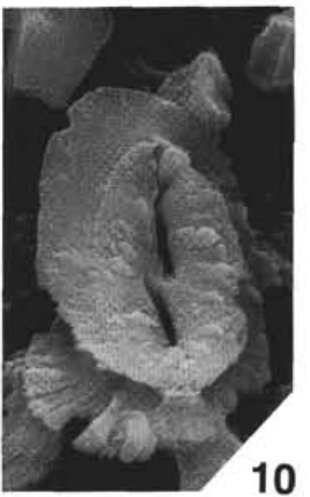

$1 \mu \mathrm{m}$

Plate 1. All figures are SEM micrographs. Magnifications are indicated by a bar scale below each figure. 1-2. Emiliania huxleyi; (1) Sample 139-857A-2H-5, 19-21 cm, distal view; (2) Sample 139-855C-2R-6, 84-88 cm, cold water form with solid proximal shield. 3. Emiliania pujosae, Sample 139-855C-2R-6, 84-88 cm. 4. Coccolithus sp., Sample 139-855C-9R-CC, distal view. 5. Calcidiscus leptoporus, Sample 139-856A-7R-3, 18-22 cm, proximal view. 6. Coccolithus crassipons, Sample 139-855C-9R-1, $44-48 \mathrm{~cm}$, proximal view. 7, 10. Helicosphaera wallichii, Sample 139-856A-3H-5, 74-78 cm, proximal views. 8. Gephyrocapsa Group 1, Sample 139-855A-7R-3, 18-32 cm, distal view; corrosion has sharply delineated the three or four lath-shaped elements that form the bridge. 9. Coccolithus sp., Sample 139-855A-1R-1, 94-98 cm, proximal view. 

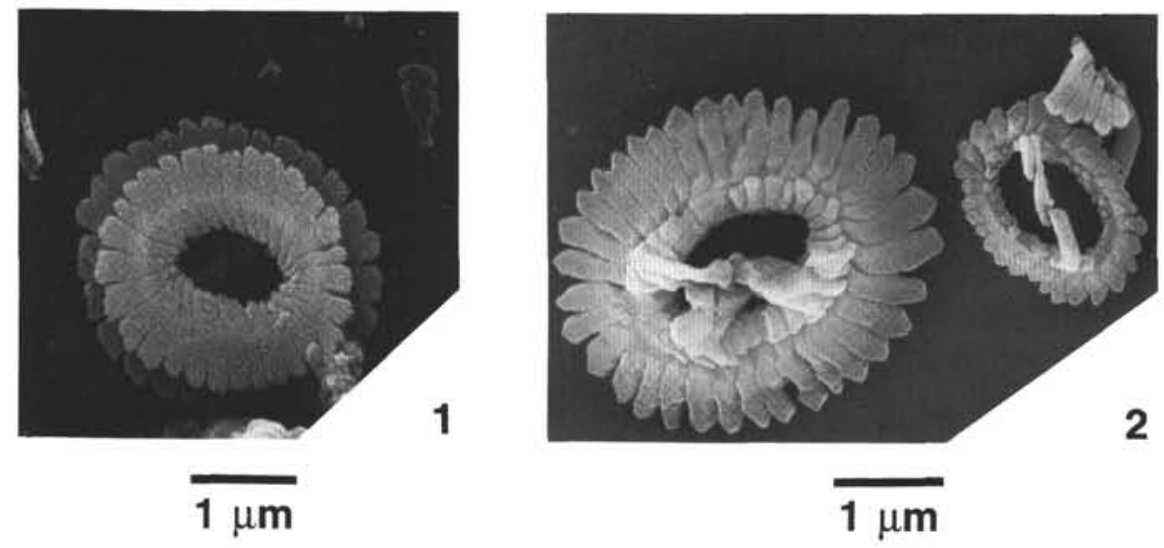

2

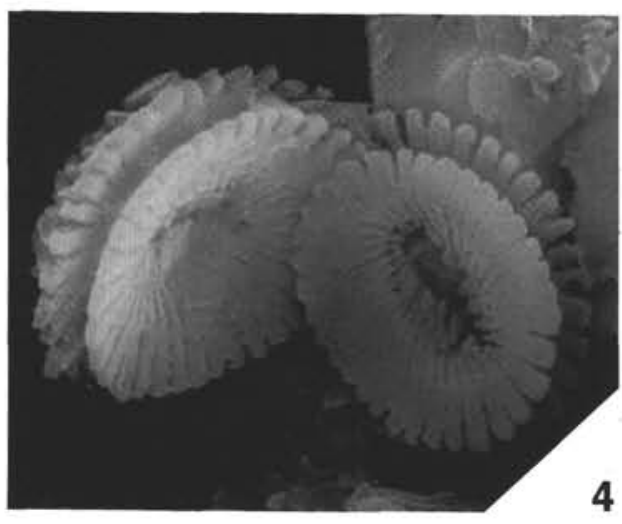

4

$\overline{1 \mu \mathrm{m}}$

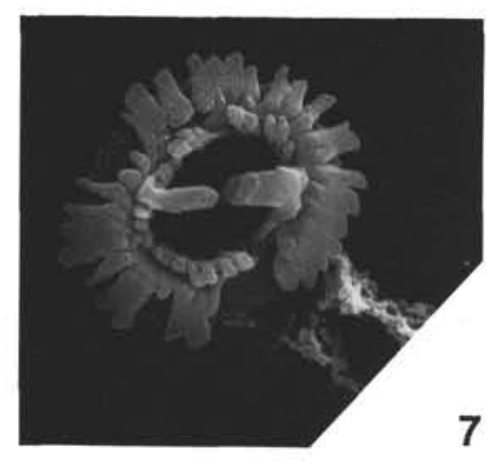

$1 \mu \mathrm{m}$
7

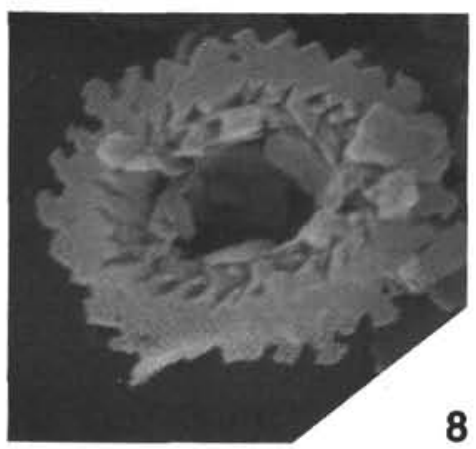

8

$1 \mu \mathrm{m}$

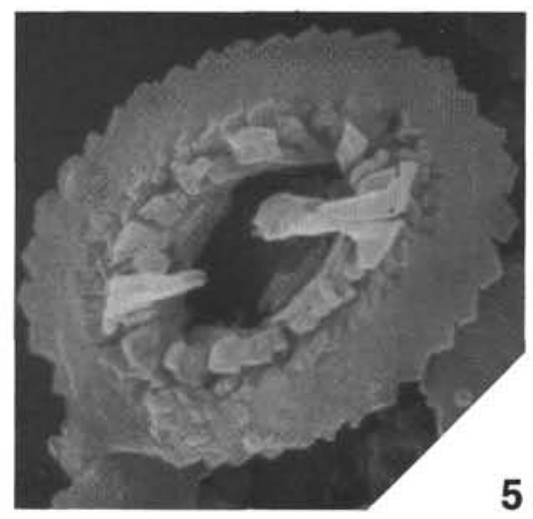

5

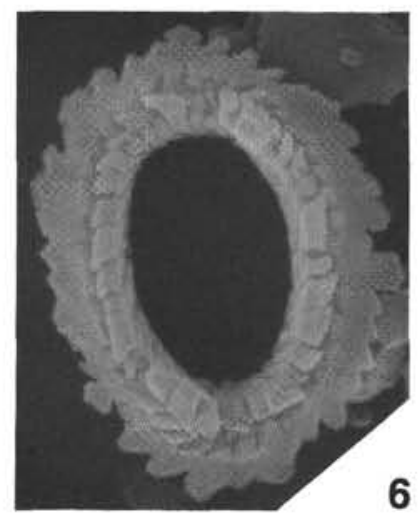

$1 \mu \mathrm{m}$

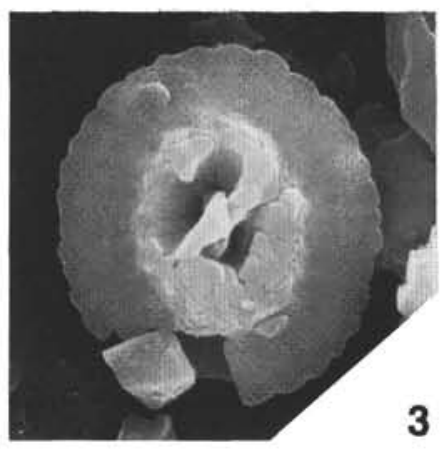

$1 \mu \mathrm{m}$

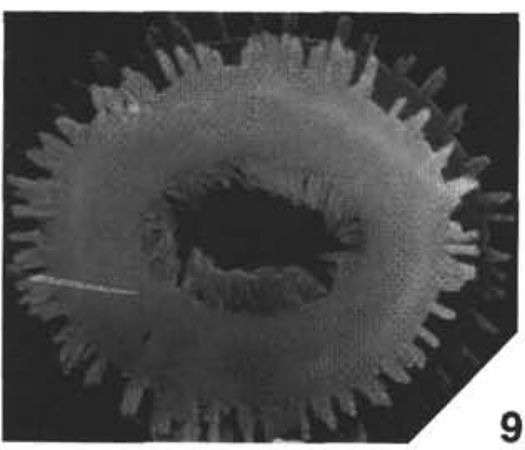

$1 \mu \mathrm{m}$

Plate 2. All figures are SEM micrographs. Magnifications are indicated by a bar scale below each figure. 1. Gephyrocapsa sp., specimen slightly dissolved, Sample 139-855A-7R-3, 18-22 cm, proximal view. 2. Gephyrocapsa Group 1 (left) and Group 2 (right), specimens slightly dissolved, Sample 139-855A-7R-3, 18-22 cm, distal views. 3,5. Gephyrocapsa Group 4, distal views. (3) Sample 139-855C-10R-5, 7-11 cm; (5) Sample 139-855A-1R-4, 94-97 cm. 4. Gephyrocapsa Group 1, specimens slightly dissolved, Sample 139-855C-9R-1, 44-48 cm, oblique proximal views. 6, 8. Gephyrocapsa Group 1, specimens dissolved and overgrown, distal views; (6) Sample 139-855A-1R-4, 94-97 cm; (8) Sample 139-855R-1, 91-94 cm. 7. Gephyrocapsa Group 1, specimen partially dissolved, Sample 139-855A-7R-3, 18-22 cm, distal view. 9. Gephyrocapsa Group 3, altered specimen with spike-like overgrowths of calcite(?) along the edges of both proximal and distal shields, Sample 139-855C-9R-1, 44-48 cm, proximal view. 


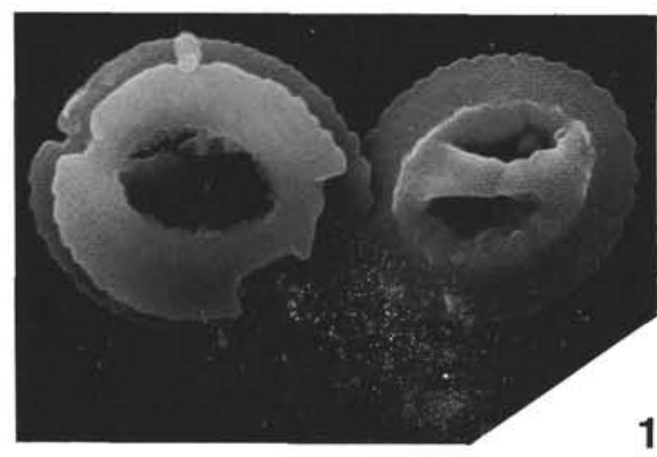

$\overline{1 \mu \mathrm{m}}$

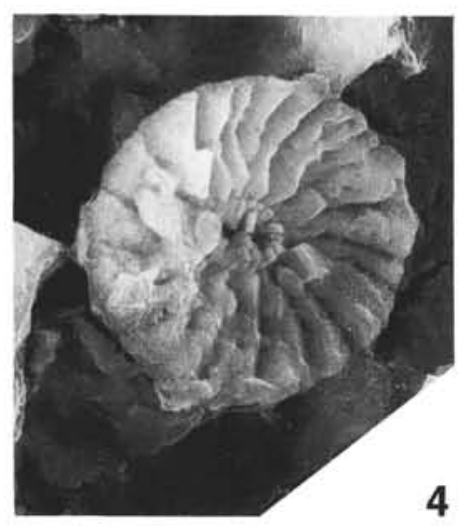

$1 \overline{\mu m}$

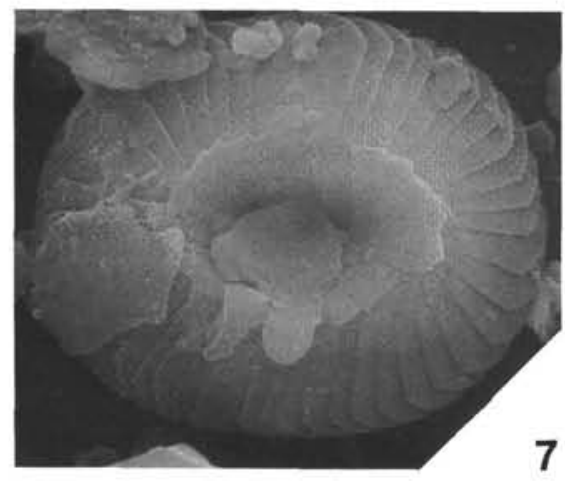

$1 \overline{\mu m}$

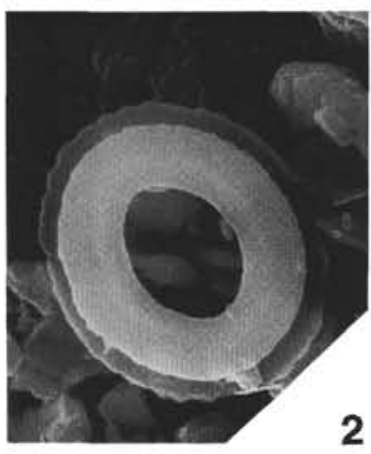

$1 \overline{\mu m}$

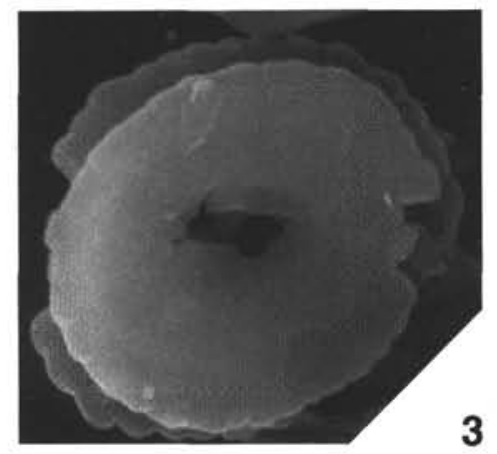

$\overline{1 \mu \mathrm{m}}$
4

7

7

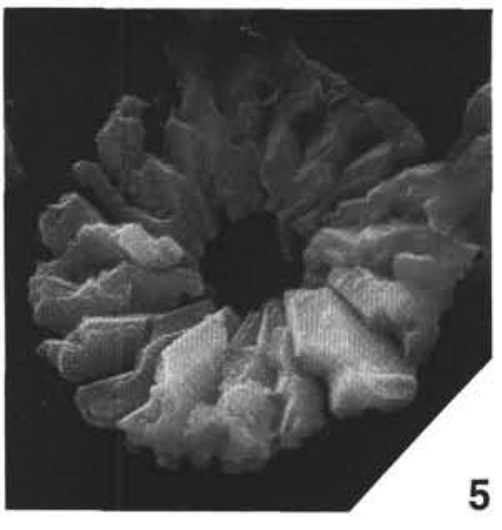

$\overline{1} \overline{\mathrm{m}}$

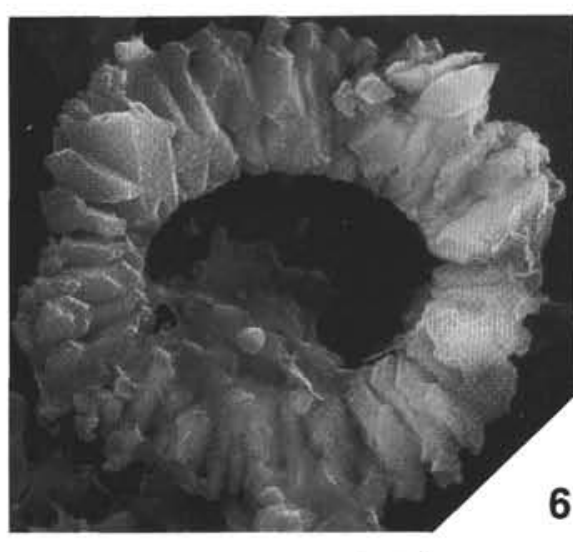

$1 \mu \mathrm{m}$

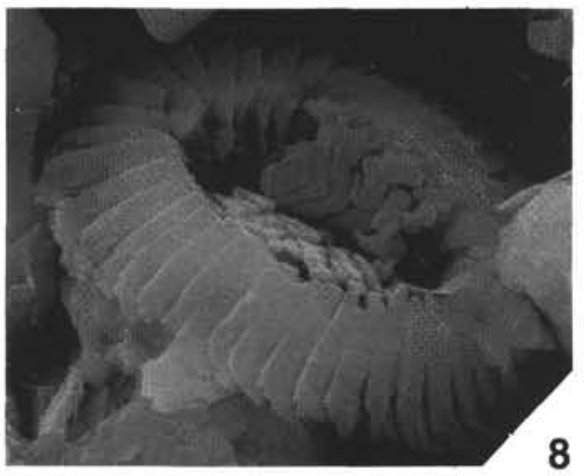

$1 \mu \mathrm{m}$

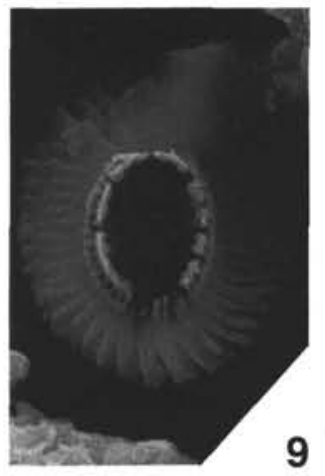

$1 \mu \mathrm{m}$

Plate 3. All figures are SEM micrographs. Magnifications are indicated by a bar scale below each figure. 1. Gephyrocapsa Group 4 (left, proximal view) and Group 3 (right, distal view), showing mixed preservation of poor (left) to moderate (right), Sample 139-857A-12X-2, 6-8 cm. 2. Gephyrocapsa Group 4, specimen corroded and missing a central bridge, Sample 139-855C-10R-5, 7-11 cm, proximal view. 3. Gephyrocapsa Group 3, corroded specimen without central bridge, Sample 139-855C-9R-1, 44-48 cm, proximal view. 4-5. Calcidiscus leptoporus, showing mixed preservations of moderate to poor (from left to right), Sample 139-856A-3H-5, 74-78 cm, proximal views. 6-9. Coccolithus pelagicus; (6) poorly preserved distal shield, Sample 139-856A-3H, 74-78 cm; (7) well-preserved specimen, Sample 139-855A-1R-1, 91-94 cm, distal view; (8-9) specimens dissolved and overgrown, distal views, [8] Sample 139-855C-9R-1, 44-48 cm; [9] Sample 139-855C-2R-6, 84-88 cm. 


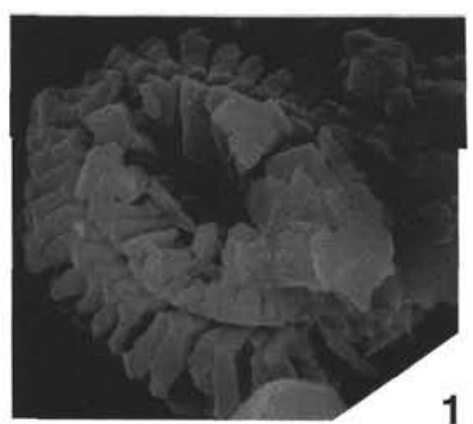

$\overline{1 \mu \mathrm{m}}$

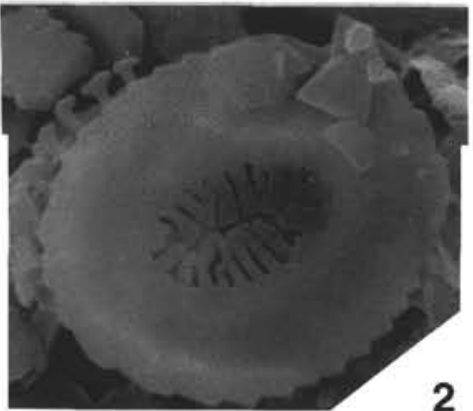

$1 \mu \mathrm{m}$

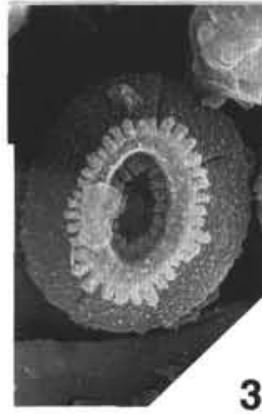

3

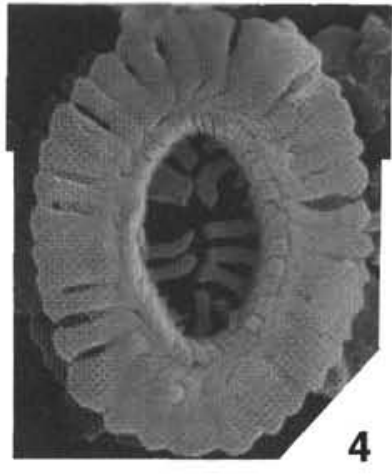

$1 \mu \mathrm{m}$

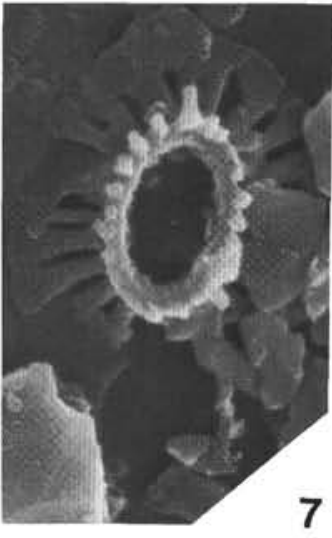

6

$1 \mu \mathrm{m}$
$1 \mu \mathrm{m}$

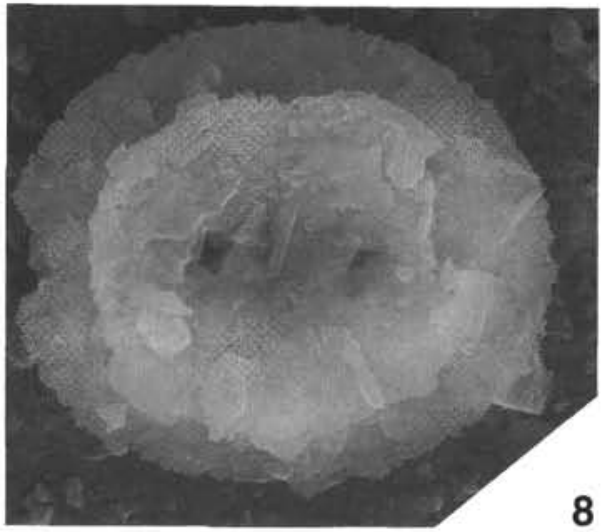

$1 \bar{m}$

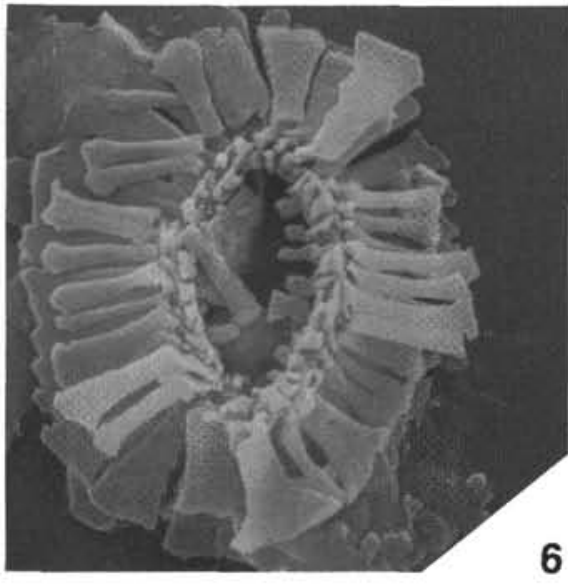

$1 \mu \mathrm{m}$

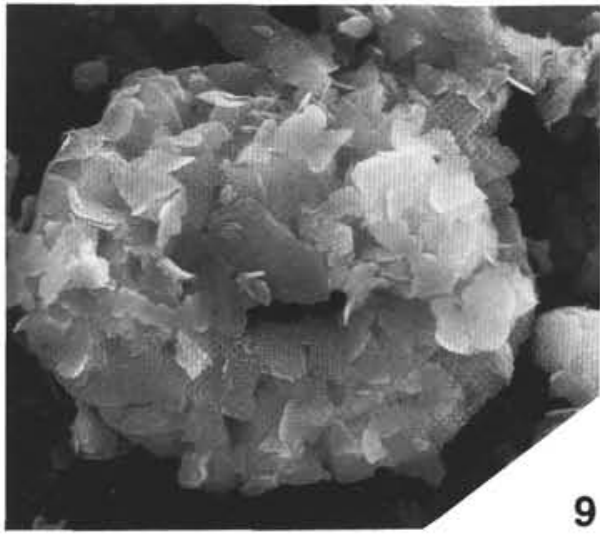

$1 \mu \mathrm{m}$

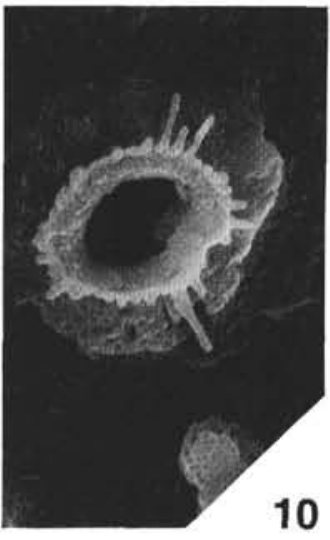

$1 \overline{\mu m}$

Plate 4. All figures are SEM micrographs. Magnifications are indicated by a bar scale below each figure. 1. Gephyrocapsa sp., specimen strongly dissolved and overgrown, Sample 139-855C-9R-1, $44-48 \mathrm{~cm}$, distal view. 2. Emiliania huxleyi, cold-water form with solid proximal shield, Sample 139-855A-4R-3, 22-24 cm. 3, 7, 10. Emiliania huxleyi, specimens with distal shields partly corroded and dissolved; (3) cold-water form with solid proximal shield, Sample 139-855C-2R-6, 84-88 cm; (7) Sample 139-857A-2H-5, 19-21 cm; (10) cold-water form with solid proximal shield, Sample 139-855A-3H-5, 74-78 cm. 4. Emiliania huxleyi, specimen with heavy overgrowth, Sample 139-856A-1R-4, 94-97 cm. 5, 6. Emiliania pujosae; (5) specimen corroded partly, Sample 139-855A-1R-4, 94-97 cm; (6) specimen corroded with overgrowth, Sample 139-855A-1R-4, 94-97 cm. 8, 9. Coccolithus pelagicus?; (8) specimen dissolved and overgrown, Sample 139-856A-5H-2,31-39 cm; (9) specimen with poor preservation (with overgrowth after dissolution), Sample 139-856 A-5H-2, 31-39 cm. 